\title{
Non-Coding RNAs in Endometrial Physiopathology
}

\author{
Alessandro La Ferlita ${ }^{1}$, Rosalia Battaglia ${ }^{1}$, Francesca Andronico ${ }^{1}$, Salvatore Caruso ${ }^{2}$, \\ Antonio Cianci ${ }^{2}$, Michele Purrello ${ }^{1}$ and Cinzia Di Pietro ${ }^{1, *}$ \\ 1 Department of Biomedical and Biotechnological Sciences, Biology and Genetics Section G. Sichel, University \\ of Catania, 95123 Catania, Italy; alessandrolf90@hotmail.it (A.L.F.); rosaliabattaglia04@gmail.com (R.B.); \\ francesca.andronico@gmail.com (F.A.); purrello@unict.it (M.P.) \\ 2 Department of General Surgery and Medical Surgical Specialties, University of Catania, 95123 Catania, Italy; \\ scaruso@unict.it (S.C.); acianci@unict.it (A.C.) \\ * Correspondence: dipietro@unict.it; Tel.: +39-095-378-2075
}

Received: 22 June 2018; Accepted: 14 July 2018; Published: 20 July 2018

\begin{abstract}
The Human Genome Project led to the discovery that about $80 \%$ of our DNA is transcribed in RNA molecules. Only $2 \%$ of the human genome is translated into proteins, the rest mostly produces molecules called non-coding RNAs, which are a heterogeneous class of RNAs involved in different steps of gene regulation. They have been classified, according to their length, into small non-coding RNAs and long non-coding RNAs, or to their function, into housekeeping non-coding RNAs and regulatory non-coding RNAs. Their involvement has been widely demonstrated in all cellular processes, as well as their dysregulation in human pathologies. In this review, we discuss the function of non-coding RNAs in endometrial physiology, analysing their involvement in embryo implantation. Moreover, we explore their role in endometrial pathologies such as endometrial cancer, endometriosis and chronic endometritis.
\end{abstract}

Keywords: miRNA; IncRNAs; endometrial cancer; endometriosis; chronic endometritis

\section{Introduction}

At the beginning of the Human Genome Project (HGP), in the late 1990s, researchers hypothesized that our genome comprised about 100,000 protein-coding genes [1]. Over the years, this number has continuously decreased. In 2001, the International Human Genome Sequencing Consortium (IHGSC) published the initial sequence of the human genome and proposed that the number of protein-coding genes was about 30,000 [2]. The end of the sequencing of the human genome in 2004 revealed that the number of genes encoding for proteins were only 20-25,000 [3]. The latest version of human GENCODE (available online: https:/ / www.gencodegenes.org/) established that the number of genes encoding for protein was 19,901 that is the $34.09 \%$ of human genes (Figure 1a). In spite of the low number of gene encoding proteins the ENCODE project, based on High Throughput Sequencing technologies and advances in bioinformatics, has provided a detailed landscape of transcription in human cells. (Figure 1b).

The non-coding RNAs (ncRNAs) could be classified, according on their size, into small ncRNAs (less than 200 nucleotides in length) and in long ncRNAs [(lncRNAs) longer than 200 nucleotides]. Alternatively, a further classification based on their function, split the ncRNAs into housekeeping and regulatory: the housekeeping ncRNAs, including ribosomal RNA (rRNA), transfer RNA (tRNA), small nuclear RNA (snRNA) and small nucleolar RNA (snoRNA), are expressed in all cell types and carry out essential functions in the cells, while the regulatory ncRNAs, including several classes of small and long molecules, assist in the regulation of gene expression, controlling different points of the central dogma (Figure 2). 


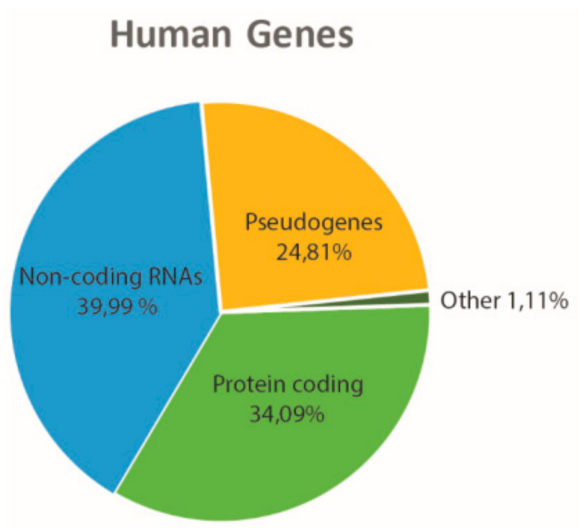

(a)

\section{Human Transcriptome}

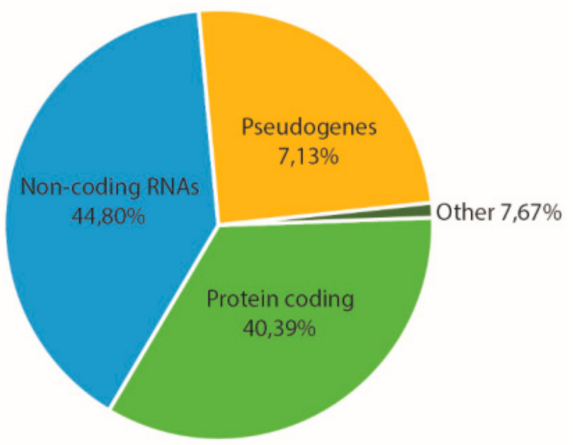

(b)

Figure 1. Overview of functional elements of the human genome and of the associated transcriptome. Pie chart showing the percentage of human genes (a) and transcripts (b) based on the current Release (Release 28, GRCh38.p12) of GENCODE. Classification is referred to Gene/Transcript Biotypes in GENCODE \& Ensembl and to VEGA descriptions (available online: http:/ / vega.archive.ensembl.org/ info/about/gene_and_transcript_types.html). The non-coding transcriptome includes both small and long non-coding RNAs; pseudogenes incorporate processed, unprocessed, transcribed, translated, polymorphic and unitary sequences; other includes IG/TCR and their pseudogenes, together with non-stop decay and non-sense mediated decay.

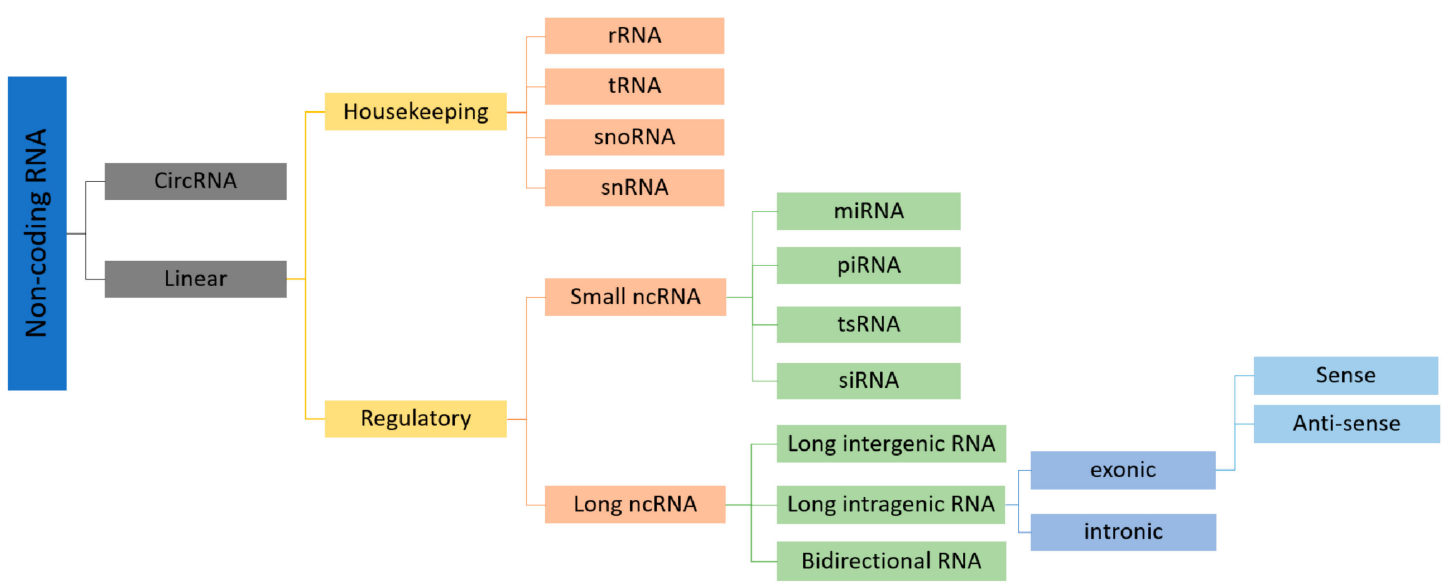

Figure 2. Schematic diagram illustrating the classification of ncRNAs according to their biological role and their length.

The interest of scientific literature in regulatory ncRNAs is generated by the important roles that these molecules perform regulating cell proliferation, differentiation, migration, cell death and angiogenesis. Consequently, their altered expression is involved in different human pathologies. Another interesting characteristic for the potential implications for human health is that ncRNAs are present in all biological fluids associated with protein complexes or enclosed within extracellular vesicles (EVs) such as microvesicles or exosomes. Extracellular ncRNAs also show altered expression in different human pathologies, thus their role has been proposed as non-invasive biomarkers, prognostic factors and also therapeutic targets in cancer or in other complex diseases. Among the regulatory ncRNAs we found: microRNAs (miRNAs), small interfering RNAs (siRNAs), Piwi-associated RNAs (piRNAs), long non-coding RNAs (lncRNAs), circular RNAs (circRNAs) and the tRNA derived small RNAs (tsRNAs) (Figure 2). To date, the most studied molecules are miRNAs, lncRNAs and circRNAs. miRNAs are long 18-25 nucleotide (nt) single-stranded RNAs, evolutionarily conserved, which negatively modulate the expression of their target mRNAs. They bind to the $3^{\prime}$ Untranslated 
Region ( $3^{\prime}$ UTR) of specific mRNA targets, leading to translational repression, or mRNA cleavage [4-6] miRNAs are very important molecules in the regulation of gene expression at the post-transcriptional level, a single miRNA can control the expression of several mRNAs and a single mRNA may be targeted by more than one miRNA, thus creating a complex network of cooperative regulation [7]. lncRNAs are the most heterogeneous class of non-protein-coding RNAs with lengths ranging from 200 to 100,000 nt. They include transcripts that may be classified as: (a) intergenic lncRNAs; (b) intronic lncRNAs; (c) sense or antisense transcripts; (d) pseudogenes; and (e) retrotransposons [8]. IncRNAs regulate gene expression at different levels, including chromatin modification, alternative splicing, protein localization and activity and can protect $3^{\prime}$ UTR of mRNAs from miRNA binding, increasing their stability [8]. Several recent studies have also shown that lncRNAs are critically involved in a wide range of biological processes, such as cell cycle regulation, pluripotency, differentiation and cell death [9-12]. CircRNAs are a recently discovered class of circular single strand RNA molecules, covalently closed, which are resistant by the exonuclease [13]. Their function and the biological process in which they are involved remain mainly unknown but recent evidence suggests that circRNAs may play an important role in RNA-RNA interactions. In some cases, circRNAs exhibit multiple binding sites for the same miRNA and for this reason it has been suggested that they could represent potential molecular sponges for sequestering the most abundant miRNAs [14]. It means that they can act as a negative regulation of miRNAs by competing, using their binding sites, with the miRNA-mRNA target interaction. Their important role in gene regulation is demonstrated by some papers, which show that deregulation of circRNAs is associated in different types of cancer [15].

Scientific community recognized the important role played by regulatory ncRNAs in cell physiology and also the effects caused by their altered expression in all human diseases but many other studies will be necessary. In fact, sometimes, we are able to identify the differential expression of one or more ncRNAs in a particular disease and also to evaluate their prognostic value but we are not able to correlate accurately specific expression profiles to specific phenotype alteration, because of the complexity and the redundancy of the circuits regulating gene expression.

In this review, we will point up the ncRNA, particularly miRNA and lncRNAs, found expressed in endometrium in physiological conditions, focusing on their involvement in embryo implantation. Moreover, we will analyse the alteration of their expression in the pathogenesis of some endometrial diseases, as endometrial cancer, endometriosis and chronic endometritis, trying to understand how their altered expressions can influence cell proliferation, differentiation and apoptosis.

\section{2. ncRNAs and Embryo Implantation}

\subsection{Embryo Implantation}

The success of embryo implantation is related to blastocyst quality as well as to the endometrium receptivity. Both the embryo and the maternal tissues are able to reciprocally exchange signals; the proper secretion of signal molecules and their uptake allow the successful implantation $[16,17]$.

Several mediators such as growth factors, cytokines, chemokines, lipids, matrix-degrading enzymes and integrins, whose expression is regulated by oestrogen $(\mathrm{E})$ and progesterone $(\mathrm{P})$, influence endometrial receptivity [18]. Many genes have been discovered that have important roles in embryo implantation and in 2011 a genomic tool was developed to assess the endometrial receptivity of woman during In Vitro Fertilization cycles (IVF). The Endometrial Receptivity Array (ERA) test, based on microarray technology, analyses the expression profile of 238 genes encoding proteins which are related with the implantation process, during the Window of Implantation (WOI). The ERA test has been shown to be more accurate than histological evaluation to assess endometrial receptivity. This has subsequently led to the new concept of personalized embryo transfer, by using endometrial biomarkers as a therapeutic strategy for patients with recurrent implantation failure [18-22] According to the rising interest in the role of ncRNAs in the regulation of gene expression, different studies have explored the involvement of miRNAs in implantation, focusing on the dialog between embryo and 
maternal tissues. Different miRNAs, associated with endometrial receptivity, have been identified in endometrial biopsies as well as in endometrial fluids (Table 1).

\section{2. miRNAs in Endometrial Receptivity}

Different studies, on animal models and humans, confirmed the important role played by miRNAs in endometrial physiology by regulating the changes in gene expression levels during the different phases of the endometrial cycle. In fact, many of them were found differentially expressed at each stage of the endometrial cycle.

MiR-30b and miR-30d were found to be significantly up-regulated and miR-494 down-regulated in the receptive endometrium $(\mathrm{LH}+7)$ compared with the pre-receptive endometrium $(\mathrm{LH}+2)$ from healthy fertile women. The bioinformatic prediction of the target genes of these miRNAs showed that they are involved in the cyclic remodelling of the endometrium, including endometrial maturation to the receptive state [23]. Mucin 1 (Muc1) is an integral transmembrane mucin glycoprotein expressed on the apical surface of the endometrium, acting as an inhibitor of embryo attachment. In mice, the expression of Muc1 decreased significantly during the WOI and could be due to a negative regulation mediated by miR-199a, let-7a and let-7b [24,25]. Insulin-like growth factor 1 receptor (IGF1R) is an important receptor, up-regulated in the endometrium during the receptive stage, which is closely related to embryo implantation. In fact, its increase on the surfaces of the endometrium might contribute to adhesive interaction with the embryo. It has been demonstrated that a high expression of miR-145 having as target the mRNA coding for IGF1R, inhibits embryo attachment. Mir-145 up-regulation has been shown in the endometrium of RIF patients [26].

Another very important characteristic for endometrial receptivity is the epithelial-mesenchymal transition (EMT). In EMT, the cells lose their polarity and display a remodelling of cell junctions in order to facilitate the interaction with embryo trophectoderm [27]. As an important suppressor of EMT, miR-429 exhibited a down-regulation during implantation in mice. Enhancement of miR-429 resulted in suppression of the migratory and invasive capacities of cells, probably through targeting protocadherin 8 , leading to reduced implantation sites [28]. On the contrary, miR-126-3p was specifically up-regulated in implantation sites, promoting cell migratory and invasive capacity by regulating the expression of integrin $\alpha 11$ [29]. Moreover, we know that sex hormones induce changes in miRNA expression in the endometrium, for example, progesterone induced the expression of miR-125b in human endometrial epithelium cells. The increased expression of miR-125b inhibits cell movement and prevents implantation, by suppressing the expression of Matrix Metallopeptidase 26 (MMP26), a member of the matrix metalloproteinase family, which is involved in degradation of the extracellular matrix [30]. These studies demonstrated that, in addition to the cyclical changes in endometrium morphology and gene expression, there exists a very complex network of miRNAs regulating the expression of many genes encoding proteins related to endometrial receptivity and implantation.

\subsection{Extracellular miRNAs in Endometrial Fluid}

To assess endometrial receptivity, many researchers are focusing their studies on extracellular ncRNAs present in endometrial fluid. Endometrial fluid is a viscous fluid secreted by the endometrial glands into the uterine cavity and its role consists in nurturing the embryo and represents the important microenvironment in which both embryo and endometrium can interact with each other [31]. The embryo, induced by cytokines and different proteins secreted by the endometrium, modulates, in turn, the secretion of integrins $\beta 3, \alpha 4$ and $\alpha 1$, interleukins, chemokines and leptine. Recently, ncRNAs have been added, as new players, in mediating the dialog between embryo and endometrium. It has been demonstrated that endometrial cells secrete exosomes in endometrial fluids and the secretion reaches a peak during WOI [32]. On the other hand, also embryos secrete extracellular vesicles in vitro that are able to be up taken by cultured endometrial cells [33]. During the last few years, the presence of miRNAs in endometrial fluid has been shown in humans and in animal models [27]. Comparing miRNA profiles between endometrial cells and exosomes present in endometrial fluid, 
13 miRNAs out of 227 were exclusively present in exosomes/microvesicles and their mRNA targets were involved in several signalling pathways associated with implantation [34]. In 2015, in a very interesting paper, the authors analysed the RNA transcript present in endometrial fluid by microarray and found that a large number of miRNAs were present in the endometrial fluid. They found 27 miRNAs differentially expressed during the WOI with respect to the four different phases of the menstrual cycle and among them miR-30d was the most up-regulated miRNA [32]. The authors also demonstrated that miR-30d is an exosomal miRNA and it is internalized by trophoblastic cells of murine embryos. Moreover, embryos treated with miR-30d exhibited increased expression of ten genes, including those encoding adhesion molecules such as Integrin Subunit Beta 3 (ITGB3), Integrin Subunit Alpha 7 (ITGA7) and Cadherin 5 (CDH5) [32]. These studies demonstrated the molecular dialog, mediated by miRNAs, between embryo and endometrium, in order to promote embryo implantation.

Table 1. miRNAs involved in embryo receptivity.

\begin{tabular}{cccc}
\hline miRNAs & Species & Sample & Reference \\
\hline mmu-let-7a & mouse & endometrium & {$[23]$} \\
mmu-let-7b & mouse & endometrium & {$[23]$} \\
hsa-let-7e* & human & exosomes from endometrial cell lines & {$[34]$} \\
hsa-let-7f-2* & human & exosomes from endometrial cell lines & {$[34]$} \\
hsa-miR-30b & human & endometrium & {$[24]$} \\
hsa-miR-30d & human & endometrium/endometrial fluid & {$[24,32]$} \\
hsa-miR-122 & human & exosomes from endometrial cell lines & {$[34]$} \\
hsa-miR-124 & human & exosomes from endometrial cell lines & {$[34]$} \\
hsa-miR-125b & human & endometrial cell lines & {$[30]$} \\
mmu-miR-126-3p & mouse & endometrium & {$[29]$} \\
hsa-miR-129* & human & exosomes from endometrial cell lines & {$[34]$} \\
hsa-miR-142-3p & human & exosomes from endometrial cell lines & {$[34]$} \\
hsa-miR-145 & human & endometrium & {$[26]$} \\
mmu-miR-199a & mouse & endometrium & {$[25]$} \\
hsa-miR-222* & human & exosomes from endometrial cell lines & {$[34]$} \\
hsa-miR-376c & human & exosomes from endometrial cell lines & {$[34]$} \\
hsa-miR-409-3p & human & exosomes from endometrial cell lines & {$[34]$} \\
mmu-miR-429 & mouse & endometrium & {$[28]$} \\
hsa-miR-432 & human & exosomes from endometrial cell lines & {$[34]$} \\
hsa-miR-451 & human & exosomes from endometrial cell lines & {$[34]$} \\
hsa-miR-494 & human & endometrium & {$[24]$} \\
hsa-miR-520h & human & exosomes from endometrial cell lines & {$[34]$} \\
hsa-miR-1248 & human & exosomes from endometrial cell lines & {$[34]$} \\
\hline
\end{tabular}

\section{3. ncRNAs and Endometrial Cancer}

\subsection{Endometrial Cancer}

Endometrial cancer (EC) is the most common gynaecological tumour in developed countries, it is the fifth most common cancer and the 14th in terms of mortality [35]. It is becoming clear that $\mathrm{EC}$, as well as many other tumours, includes different subtypes having specific genetic and molecular features. Based on histological characteristics, specific protein expression and grade, EC has been classified into two subtypes [36]. Type 1, also called endometrioid type (EEC), represents $70-80 \%$ of new sporadic cases. These cancers are typically well differentiated, associated with increasing oestrogen levels and the patients have a favourable prognosis. On the molecular level, more than $80 \%$ type I tumours are associated with a decreased or lacking expression of Phosphatase and tensin homolog (PTEN) and to an overexpressed Oestrogen Receptor (ER), which promote a deregulated cellular proliferation [37-40]. Furthermore, EEC are frequently associated with microsatellite instability (leading to DNA mismatch repair), genetic mutations and epigenetic abnormalities [41]. Type 2, known as non-endometrioid endometrial carcinoma (NEEC), is not related to circulating oestrogen levels 
and it is less common than type 1 (10-20\% of ECs) [42]. Patients with NEEC, usually have a poor prognosis because the tumour is typically diagnosed when metastases are already present [36]. On the molecular level, NEEC tissue samples show a high expression of Tumour Protein p53 (TP53) and Cyclin Dependent Kinase inhibitor 2A (CDKN2A or P16), resulting in non-functional proteins that accumulate in the cell acting as a double negative inhibitor of the wild-type p53, leading to propagation of aberrant cells and to uncontrolled cell growth [43].

Many papers have investigated the role of ncRNA in EC in an attempt to find new molecular markers able to discriminate the different subtypes, predict prognosis and design new drugs for personalized targeted therapies [44-47]. In this review, we focused our attention on more important biological pathways and processes altered in EC and we discussed the role of ncRNAs in their regulation.

\section{2. miRNAs in Endometrial Cancer}

The phosphatidylinositol 3-kinase (PI3K) pathway is involved in the control of growth, survival, proliferation and apoptosis. Gain- or loss-of-function mutations of genes encoding proteins involved in the pathway lead to neoplastic transformations and it has been demonstrated that several components are dysregulated also in EC [48]. PTEN is a tumour suppressor that negatively regulates the PI3K-AKT signalling pathway. Loss of its function is implicated in the pathogenesis of a number of different tumours, including endometrial carcinoma [49]. PTEN mRNA is negatively regulated by miR-205 and it has been demonstrated that miR-205 up-regulation leads to increased B-cell lymphoma 2 (BCL2) levels and TP53 down-regulation, inhibiting tumour cell apoptosis and enhancing proliferation [50]. Moreover, by stimulating the AKT pathway and inhibiting glycogen synthase kinase $3 \beta$ (GSK3B), miR-205 suppresses E-cadherin expression and promotes SNAIL expression [51]. Transfecting endometrial cancer cells with LNA-miR-205-inhibitor (Locked Nucleic Acid-inhibitor of miR-205), Torres et al. recently obtained decreased endometrial cancer cell proliferation in vitro and in vivo [52]. PTEN can also be controlled by miR-21, involved in enhanced malignant transformations and proliferation of type 1 EC cells [53]. The transcription factor Forkhead Box O1 (FOXO1), belonging to the Forkhead Box class O family, is a downstream target of the PI3K pathway and it is able to regulate different biological processes involved in endometrial phases such as menstruation, uterine cell regeneration, tissue remodelling and cell differentiation [54,55]. In EC type 1, FOXO1 is down-regulated and it has been shown that miR-9, miR-27, miR-96, miR-153 and miR-182, able to target FOXO1 mRNA, are over expressed in the same cells [56]. On the other hand, Forkhead Box C1 (FOXC1), another member of the forkhead box transcription factors, is an oncogene controlling tumour cell migration and metastasis and it is inhibited by miR-204 [57]. MiR-204 down-expression has been associated with solid tumour development, such as in the lung and gastric and endometrioid endometrial cancer [57-59]. The hyperactivation of the PI3K pathway leads to an inhibition of apoptosis by the repression of BCL2 associated agonist of cell death (BAD) and the enhancement of BCL2 activity [60]. On the other hand, apoptosis inhibition in EC can occur through BCL2 overexpression and BCL2 associated X (BAX) downregulation promoted by higher oestrogen levels. One of the most important regulator families involved in this mechanism seems to be the let-7 miRNA family, that is, let-7a, let-7b, let-7c, let7d, let-7e, let-7f and let-7g, whose expression grows in response to oestrogen exposure [61]. Nevertheless, high levels of let-7 are related to low malignancy of type I endometrial cancer, suggesting that these molecules could have dual oncogenic and cancer-suppressive effects in endometrial cancer cells. Another important protein, often evaluated to assess an aetiology-specific therapy in type $1 \mathrm{EC}$ patients, is ER $\alpha$ [62]. Its amplification was regarded as a prevalent event in endometrial cancer, however, a decreased ER $\alpha$ level has been detected in high-stage and poorly differentiated cancers [63-65]. ER $\alpha$ seems to be suppressed by miR-206, leading to an anti-proliferation effect and decreased invasion capacity [66]. IGF1R, by binding its IGF1 and IGF2 ligands, is able to activate the PI3K pathway, stimulating cell proliferation and inhibiting apoptosis. Therefore, if it is over-expressed, as in most malignant tissues, it plays an anti-apoptotic role, promoting cancer cell survival and tumour 
metastasis $[67,68]$. Recent studies demonstrated that IGF1R was highly expressed in EC tissues and it was inversely correlated with miR-381 levels [69].

Epigenetic mechanisms seem to be involved in EC: silencing of DNA mismatch repair genes by DNA hypermethylation has been demonstrated [70]. Moreover, the study of methylation profiles in endometrial tumorigenesis showed that, among different tumour suppressor genes, the number of methylated promoters increased in the progression of cancer [71]. For example, miR-129-2 seems to be related to microsatellite instability and mutL homolog 1 (MLH1) methylation, which is frequently observed in EC cells, suggesting an important role in early stages of carcinogenesis [72,73]. Usually, miR-203 suppresses tumour proliferation, invasion and metastasis, through the inactivation of ABL proto-oncogene 1 (ABL1) and BCR-ABL1 oncogenes. In hematopoietic tumours, it has been found silenced by the hypermethylation of its promoter [74]. Huang and collaborators found its hypermethylation in EC cells lines and they observed that it was associated with microsatellite instability and MLH1 methylation in primary endometrioid EC [75]. Mir-152 is a tumour suppressor, which inhibits tumour cell growth both in vitro and in vivo by repressing Cell Division Cycle 25B (CDC25B), an important cell cycle regulator [76]. It is able to target E2F Transcription Factor 3 (E2F3), DNA methyltransferase 1 (DNMT1), met proto-oncogene (MET) and Rapamycin-insensitive companion of mTOR (Rictor) and in EC cells it seems to be down-regulated through CpG hypermethylation, promoting cancer development and progression [77].

Several miRNAs that regulate EMT have been found deregulated in EC. EMT, important in implantation, is also a key process in oncogenesis and tumour metastasis; it has been mainly related to the expression of three markers: epithelial E-cadherin, mesenchymal vimentin and N-cadherin [78]. MiR-93 has been described as a tumour suppressor in ovarian cancer and more recently as an oncomiR in EC cells. MiR-93 up-regulation leads to a downregulated E-cadherin and increased N-cadherin expression [79]. In addition, this miRNA seems to be able to target FOXA1, a negative regulator of EMT, down-regulated in EC cells $[79,80]$. Another miRNA involved in EMT processes is miR-30c, which targets Metastasis-associated gene-1 (MTA1) inhibiting cell proliferation, metastasis and invasion in EC cells [81]. It is down-regulated both in type 1 and type 2 EC cells and its expression seems to be related to oestrogen concentration [82]. MiR-106b has been related to EMT, too: it has been associated with Twist family bHLH transcription factor 1 (TWIST1) targeting [83]. TWIST1 contributes to the EMT phenotype in EC cells improving cell invasion and it is more expressed in EC cells than in normal ones [84]. These findings are consistent with miR-106b downregulation in EC cells showing EMT phenotypes; profiling its expression levels might be helpful for predicting the risk of metastasis, especially in patients with type II EC [83].

\subsection{Circulating miRNA and Endometrial Cancer}

To discriminate the different subtypes and predict prognosis by using circulating miRNAs as non-invasive biomarkers of EC, several investigations have investigated their expression profiles in serum or plasma. High serum levels of miR-155 have been found associated with cancer stage and lymph node metastasis [85]. Another study demonstrated that the association of miR-99a and miR-199b, up-regulated in plasma of EEC patients, better discriminate EEC patients [86]. A recent study demonstrated that down-regulated miR-29b expression in plasma correlates with poor EC prognosis and is helpful to evaluate the EC prognosis [87]. A genome-wide study on miRNA expression profiles from plasma of EEC and subsequent validation by quantitative reverse-transcriptase polymerase chain reaction demonstrated the significant up-regulation of 5 miRNAs (miR-15b, miR-27a, miR-223, miR-3145 and miR-4638). Moreover, the authors found that miR-27a and CA125 together have a considerable clinical value in diagnosing EEC [88].

In summary, a lot of miRNAs, cellular and circulating, have been found dysregulated in endometrial cancer and a comprehensive list and the relative references are reported in Table 2 [89-114]. 
Table 2. miRNAs differentially expressed in endometrial cancer (EC) patients.

\begin{tabular}{|c|c|c|c|}
\hline miRNAs & Expression & Sample & Reference \\
\hline Has-let-7 miRNAs & up & EEC & [61] \\
\hline miR-let-7a & down & $\mathrm{EC}$ & [89] \\
\hline miR-let-7b & down & EC & {$[90]$} \\
\hline $\operatorname{miR}-9$ & up & EEC & [56] \\
\hline miR-10b & up & $\mathrm{EC}$ & [91] \\
\hline miR-15a-5p & down & $\mathrm{EC}$ & [92] \\
\hline $\operatorname{miR}-15 b$ & up & Plasma in EEC patients & [88] \\
\hline $\operatorname{miR}-21$ & up & EEC & [53] \\
\hline $\operatorname{miR}-23 a$ & down & EEC & [93] \\
\hline miR-24 & down & $\mathrm{EC}$ & [94] \\
\hline $\operatorname{miR}-27 a$ & up & EEC, Plasma in EEC patients & {$[56,88]$} \\
\hline $\operatorname{miR}-29 b$ & down & EC, Plasma & {$[87,95]$} \\
\hline $\operatorname{miR}-30 \mathrm{c}$ & down & EC & {$[81,82]$} \\
\hline $\operatorname{miR}-31$ & up & $\mathrm{EC}$ & {$[96]$} \\
\hline $\operatorname{miR}-34 \mathrm{c}$ & down & $\mathrm{EC}$ & [97] \\
\hline miR-96 & up & EEC & [56] \\
\hline miR-99a & up & Plasma in EEC & [86] \\
\hline miR-106b & down & $\mathrm{EEC}$ & [83] \\
\hline miR-125b & down & EEC & [98] \\
\hline miR-129 & down & $\mathrm{EC}$ & [99] \\
\hline miR-129-2 & down & $\mathrm{EC}$ & [72] \\
\hline miR-135a & up & $\mathrm{EC}$ & [100] \\
\hline miR-139-5p & down & $\mathrm{EC}$ & [101] \\
\hline miR-141 & up & EEC & [102] \\
\hline miR-143 & down & $\mathrm{EC}$ & [103] \\
\hline miR-145 & down & EEC & [104] \\
\hline miR-148b & down & $\mathrm{EC}$ & [105] \\
\hline miR-152 & down & $\mathrm{EC}$ & [76] \\
\hline miR-153 & up & $\mathrm{EC}$ & [56] \\
\hline miR-155 & Up & Serum & [85] \\
\hline miR-181c & down & EEC & [106] \\
\hline miR-182-5p & up & EEC & {$[56,102]$} \\
\hline miR-183-5p & up & $\mathrm{EC}$ & {$[108]$} \\
\hline miR-194 & down & $\mathrm{EC}$ & [109] \\
\hline miR-199b & up & Plasma in EEC patients & [86] \\
\hline $\operatorname{miR}-200 a^{*}$ & up & EC & {$[102,108]$} \\
\hline miR-200b & up & EEC & [102] \\
\hline $\operatorname{miR}-200 c-3 p$ & up & $\mathrm{EC}$ & [110] \\
\hline miR-203 & down & $\mathrm{EC}$ & [74] \\
\hline miR-204 & down & $\mathrm{EC}$ & [57] \\
\hline miR-205 & up & EEC & {$[50,51,102]$} \\
\hline $\operatorname{miR}-206$ & down & $\mathrm{EC}$ & [66] \\
\hline $\operatorname{miR}-223$ & up & Plasma in EEC & [88] \\
\hline miR-361 & down & $\mathrm{EC}$ & [90] \\
\hline $\operatorname{miR}-375$ & up & $\mathrm{EC}$ & [100] \\
\hline $\operatorname{miR}-381$ & down & $\mathrm{EC}$ & [69] \\
\hline $\operatorname{miR}-424$ & down & $\mathrm{EC}$ & [111] \\
\hline miR-503 & down & EEC & [112] \\
\hline miR-944 & up & $\mathrm{EC}$ & [113] \\
\hline miR-1271 & down & $\mathrm{EC}$ & [114] \\
\hline miR-3145 & up & Plasma in EEC patients & [88] \\
\hline $\operatorname{miR}-4638$ & up & Plasma in EEC patients & [88] \\
\hline
\end{tabular}

\subsection{IncRNAs in Endometrial Cancer}

To date, there are no studies about lncRNA profiles during physiological endometrial changes but their altered expression in EC as well as in endometriosis has been demonstrated [115-117]. 
In fact, different lncRNAs seem to be differentially expressed in EC and some of them could have a prognostic value. Ovarian adenocarcinoma amplified lncRNA (OVAAL) is overexpressed in many ovarian serum carcinoma, as well as in type 1 EC but less frequently in type 2 EC $[46,118]$. Its over expression is related to overexpression of p53-regulated genes [118]. Metastasis-associated lung adenocarcinoma transcript 1 (MALAT1) is an $8000 \mathrm{nt}$ lncRNA, upregulated in many different human tumours. It has been positively associated with hyperplasia and negatively with metastasis, thus it can be used as a predictive biomarker. Its expression is regulated by the Wnt/ $\beta$-catenin signalling pathway, frequently abnormally enhanced in endometrioid type EC. Particularly, MALAT1 has been identified as a functional downstream target of Protocadherin 10 (PCDH10), a tumour suppressor protein, down-regulated in EEC [119]. Growth arrest-specific 5 (GAS5) is a tumour suppressor gene, implicated and aberrantly expressed in multiple cancers [120-124]. Recent evidences show that this lncRNA is down-regulated in endometrial cancer cells, being able to induce their apoptosis by inducing PTEN expression through inhibiting miR-103, which usually stimulates cell growth and invasion in endometrial carcinoma [125]. HOX transcript antisense intergenic RNA (HOTAIR) is one of the most studied lncRNAs, because of its involvement in genome modification: in fact, it can repress gene expression through the activation of chromatin modifiers [126]. Its overexpression is associated with increasing oestrogen levels and correlated with poor cancer prognosis. HOTAR has been found upregulated in EC compared to normal endometrium samples. HOTAIR overexpression is also associated with increased metastatic spread and a reduced overall-survival rate in EC [127]. Using a mouse xenograft EC model, treated with HOTAIR siRNA lentivirus, a significant tumorigenesis rate and tumour size reduction occurred both in vitro and in vivo [128]. This shows that HOTAIR may be a prognostic molecular marker for EC, even if further studies are required to demonstrate its involvement in endometrial cancer progression and metastasis [127] H19, a paternally imprinted lncRNA, is located on chromosome 11 and lies within $200 \mathrm{kbp}$ downstream of the IFG2 gene [129]. H19 is also known as "oncofetal non-coding RNA" because it is primarily expressed during foetal development, so it is absent or poorly expressed in most normal adult tissues. Its re-expression has been detected in various cancers, including ovarian cancer [130-133]. H19 expression levels increase throughout endometrial epithelium tumorigenesis: they are low in normal epithelium, higher in hyperplastic endometrium, very high in EC and even higher in dedifferentiated tumour tissues [115]. Urothelial Cancer-Associated 1 (UCA1) is one of the lncRNAs mostly associated with tumour progression, metastasis and chemo-resistance in several cancer types [134-138]. Lu et al. discovered that UCA1 levels were significantly higher in EC cells than in normal endometrial samples and in metastatic EC they noticed a further level increase if compared to primary tumour, suggesting its involvement in tumour cell migration [139]. The circRNAs, another class of ncRNAs, has been shown to be enriched and stable in exosomes. They act as natural miRNA sponges to decrease miRNA levels, reducing their regulatory effect on mRNAs $[140,141]$. In a recent study, $X u$ et al. found that the number of exosomes isolated from serum of EC patients was higher than those of normal samples. In addition, the expression profile of circRNAs in serum of EC patient was dysregulated [142]. Another analysis found several circRNAs differentially expressed in EC cells when compared to normal endometrium [143]. In Table 3, we present a list of significant lncRNAs deregulated in EC and the relative references [144-156]. 
Table 3. IncRNAs differentially expressed in EC patients.

\begin{tabular}{cccc}
\hline IncRNAs & Expression & EC Type & Reference \\
\hline ASLNC04080 & up & EC & {$[144]$} \\
BANCR & up & EEC & {$[145]$} \\
CARLo-5 & up & EC & {$[146]$} \\
CCAT2 & up & EC & {$[147]$} \\
FER1L4 & down & EC & {$[148]$} \\
GAS5 & down & EC & {$[125]$} \\
H19 & up & EC & {$[115]$} \\
HAND2-AS1 & down & EEC & {$[149]$} \\
HOTAIR & up & EC & {$[127]$} \\
LA16313D11.11 & down & EC & {$[150]$} \\
LINC00672 & down & EC & {$[151]$} \\
LINC01016 & up & EC & {$[152]$} \\
MALAT1 & down & EEC & {$[119]$} \\
MEG3 & down & EC & {$[153]$} \\
NEAT1 & up & EEC & {$[154]$} \\
OVAL & up & EEC & {$[46,118]$} \\
RP11395G12.3 & down & EC & {$[150]$} \\
SNHG8 & up & EC & {$[155]$} \\
TUSC7 & down & EC & {$[156]$} \\
UCA1 & up & EC & {$[139]$} \\
\hline
\end{tabular}

\section{4. ncRNAs and Endometriosis}

\subsection{Endometriosis}

Endometriosis is a disabling disorder characterized by the presence of endometrial tissues outside of the uterine cavity. The most common symptoms are non-menstrual pelvic pain, dyspareunia and infertility [157]. The exact causes are unknown, even if the most shared theory is retrograde menstruation, that is endometrial cells through menstrual blood move in on pelvic cavity. These cells present different characteristics, as the ability of adhesion, aggression, neo-angiogenesis and inhibition of apoptosis, which make endometriosis similar to cancer $[158,159]$.

Although decades of research about the pathogenesis of endometriosis have shown the role of hormonal and non-hormonal mechanisms related to disease development, the therapeutic approach and the methods for early diagnosis are still lacking. Today, the best method for the diagnosis of endometriosis remains laparoscopic surgery but the finding new biomarkers for a minimally invasive diagnosis represent an important scientific challenge [160].

\section{2. miRNAs and Endometriosis}

Different papers have been published about miRNAs potentially involved in endometriosis but unfortunately, many times the concordance among the results is small. This could be due to the heterogeneity of cell types used in the experiments, as illustrated in a recent review [161]. Another possible explanation is that various technologies (deep-sequencing, microarray, Real-Time PCR) have been used by different researchers.

The first studies on miRNAs and endometriosis demonstrated that different miRNAs were differentially expressed in endometrial tissues with endometriotic lesions with respect to endometrial tissues of the same woman without endometriotic lesions $[162,163]$. Burney et collaborators were among the first authors to publish the difference in expression profiles of miRNAs between eutopic endometrial tissues of woman with and without endometriosis [164]. They found that four miRNAs (miR-34c-5p, miR-9, miR-9*, miR-34b*) were down-regulated in women with endometriosis compared to controls. In another paper, the authors showed that in patients with ovarian endometriosis, miR-483-5p, targeting IGF2 and miR-629-3p were down-regulated in the eutopic endometrium. 
These authors suggest that the dysregulation of these miRNAs and their target genes could contribute to the overgrowth of endometrial tissue outside the uterus [165]. Further studies have been carried out in the last few years on miRNAs and endometriosis. In 2017, Min Kyoung Kim and collaborators demonstrated that the expression of miR-27b-3p, upregulated in human endometrial stromal cells from patients with endometriosis, is reduced after the treatment with Rg3-enhanced red ginseng extract (Rg3E). The authors showed the same effects in vivo in a mouse model [166]. In 2018, by RNA sequencing, it was demonstrated that 107 miRNAs and 6112 mRNAs were differentially expressed in ectopic endometrium. The authors built regulatory networks among Transcription Factors, miRNAs and mRNA targets identifying the most important points of altered regulation in ectopic tissue. Among the miRNAs, they found that some members of miR-449 and miR-34b/c cluster, miR-200 family, miR-106a-363 cluster were dysregulated [167] (Table 4). Members of miR-200 family are also involved in cell migration and EMT which supposedly occurs in the pathogenesis of endometriosis [161]. The downregulation of members of miR-200 family in endometrial tissues with endometriotic lesion results in increased expression of ZEB1/ZEB2 which are transcriptional repressors of E-cadherin. E-cadherin, in the normal endometrial tissue, is required for maintaining the epithelial nature of cells and their adhesion. Its down-regulation leads to epithelial cells to acquire mesenchymal characteristics [161].

Neoangiogenesis regulators such as Vascular Endothelial Growth Factor A (VEGFA) and Thrombospondin-1 (THBS1) have been involved in the pathology of endometriosis [168]. Two different groups of researchers reported that miR-17-5p and miR-20a were down-regulated in the ovarian endometrium compared to eutopic endometrium [165,169] Braza-Boils and collaborators, in 2013, reported that the miR-17-92 cluster increases tumour neovascularization by decreasing THBS1 expression [170]. MiR-15a-5p, a negative regulator of VEGFA, has been found down-regulated in endometrium samples of woman with endometriosis and VEGFA was found up-regulated in the same endometrial tissues. Moreover, the transfection of endometriosis stromal cells with miR-15a-5p mimics led to reduction in the expression of VEGFA and migration abilities of the endometrial stromal cells, suggesting an important role of this miRNA in the pathogenesis of endometriosis [171].

It has been demonstrated that endometriotic cells in vitro are able to secrete miRNA EV cargo, in culture medium and the role of extracellular miRNAs in the pathogenesis of endometriosis has also been studied. Harp and collaborators observed that miR-21, pro-angiogenic miRNA, is up-regulated in exosomes from endometriosis samples compared with exosomes from controls. The authors suggested that exosomes play autocrine/paracrine roles in the development of endometriosis, potentially by modulating angiogenesis [172].

\subsection{Circulating miRNAs as Biomarkers of Endometriosis}

Due to the anatomical location of this disease, several closely related biological fluids have been proposed as source for non-invasive biomarkers of endometriosis, for example: urine, plasma/serum and menstrual blood. One potential use of circulating miRNAs as non-invasive biomarkers for endometriosis is an ongoing area of research and its diagnostic and therapeutic implications have been extensively reviewed [164,173-175]. In 2013, Wang and collaborators performed a circulating miRNA array profiling in serum and they found different deregulated miRNAs [176] (Table 4). Moreover, a microarray analysis revealed that miR-17-5p, miR-20a and miR-22 were down-regulated in plasma from patients with endometriosis [177]. It is known that prognostic value increases when two or more biomarkers are evaluated at the same time, in fact, two studies performed in serum and plasma demonstrated that let-7b, let-7d and let-7f altered levels, as well as miR-200a-3p, miR-200b-3p and miR-141-3p down-regulation are able to discriminate patients with endometriosis from controls $[160,178]$ (Table 4). 
Table 4. miRNAs differentially expressed in Endometriosis patients.

\begin{tabular}{|c|c|c|c|}
\hline miRNAs & Expression & Sample & Reference \\
\hline let-7b & down & serum & [160] \\
\hline let-7d & down & serum & [160] \\
\hline let-7f & down & serum & [160] \\
\hline miR-9 & down & endometrium & [164] \\
\hline miR-9* & down & endometrium $\backslash$ serum & {$[164,176]$} \\
\hline miR-15a-5p & down & endometrium & [171] \\
\hline $\operatorname{miR}-17-5 p$ & down & ovarian endometrium \plasma & {$[165,169,177]$} \\
\hline $\operatorname{miR}-20 a$ & down & ovarian endometrium $\backslash$ plasma & {$[165,169,177]$} \\
\hline $\operatorname{miR}-20 b-5 p$ & down & endometrium & [167] \\
\hline $\operatorname{miR}-21$ & up & endometrial exosomes & [172] \\
\hline $\operatorname{miR}-22$ & down & plasma & [175] \\
\hline $\operatorname{miR}-27 b-3 p$ & up & endometrium & [166] \\
\hline miR-30d-5p & down & endometrium & [167] \\
\hline $\operatorname{miR}-34 b^{*}$ & down & endometrium & [164] \\
\hline $\operatorname{miR}-34 c-5 p$ & down & endometrium & [164] \\
\hline miR-106a-5p & down & endometrium & [167] \\
\hline $\operatorname{miR}-122$ & up & serum & [176] \\
\hline $\operatorname{miR}-133 b$ & up & endometrium & [167] \\
\hline miR-135a & down & serum & [160] \\
\hline $\operatorname{miR}-141^{*}$ & down & serum & [176] \\
\hline miR-141-3p & down & endometrium $\backslash$ plasma & {$[167,176]$} \\
\hline $\operatorname{miR}-145^{*}$ & down & serum & [176] \\
\hline miR-182-5p & down & endometrium & [167] \\
\hline miR-183-5p & down & endometrium & [167] \\
\hline miR-196b-5p & down & endometrium & [167] \\
\hline miR-199a & up & serum & [176] \\
\hline miR-200a-3p & down & endometrium $\backslash$ plasma & {$[161,167,178]$} \\
\hline miR-200b-3p & down & endometrium $\backslash$ plasma & {$[161,167,178]$} \\
\hline $\operatorname{miR}-200 c-3 p$ & down & endometrium & {$[161,167]$} \\
\hline miR-363-3p & down & endometrium & [167] \\
\hline $\operatorname{miR}-449 a$ & down & endometrium & [167] \\
\hline miR-449b-5p & down & endometrium & [167] \\
\hline $\operatorname{miR}-483-5 p$ & down & endometrium & [165] \\
\hline miR-542-3p & down & serum & [176] \\
\hline miR-629-3p & down & endometrium & [165] \\
\hline
\end{tabular}

\section{4. $\ln \mathrm{R} N A \mathrm{~s}$ and Endometriosis}

In a paper published in 2015, Wang and collaborators compared the expression of several lncRNAs and mRNAs between eutopic and normal endometrium by microarray analysis and validated the obtained data using RT-qPCR. The authors found several lncRNAs and mRNAs differentially expressed between eutopic and normal endometrium. Specifically, among the lncRNAs, 488 were up-regulated and 789 down-regulated and among the mRNAs, 578 were over expressed and 638 down-regulated [117]. The most significantly up-regulated lncRNA is AC068282.3 (fold change 31.3) while RP11-403H13.1 is the most significantly down-regulated one (fold change 44.3). The differentially expressed lncRNAs were involved in cell cycle regulation and immune response [117]. As previously described, H19 is a lncRNA, which is expressed from the imprinted locus that also contains the reciprocally imprinted IGF2 gene. It has been shown that H19, reducing the bioavailability of miRNA let-7, by acting as a molecular sponge, was significantly down-regulated in the eutopic endometrium of women with endometriosis. Its down regulation, increasing let-7 activity, inhibited IGF1R expression. Accordingly, the proliferation of endometrial stromal cells was reduced. This paper represents the first example of lncRNA involvement in the pathogenesis of endometriosis and its association with infertility [179]. 
Another lncRNA that is important in endometriosis is MALAT1. This is one of the most known lncRNAs, it is evolutionary well-conserved and is overexpressed in many cancers [180-183]. Recently, a paper demonstrated that the expression of MALAT1 is significantly increased during endometriosis. Moreover, the authors showed that miR-200c, which is regulated by MALAT1, was significantly down-regulated in endometrial samples from woman with endometriosis and they were significantly negatively correlated. The functional assay showed that overexpression of miR-200c inhibited the proliferation of Human Endometrial Stromal Cells (HESCs) while the inhibition of miR-200c promoted cellular proliferation. Similar results were also obtained from the migration assay in which MALAT1 knockdown inhibits the proliferation and migration of HESCs [184]. Finally, the presence of deregulated lncRNAs in serum as potential non-invasive biomarkers of endometriosis has been investigated. In 2016, it has been reported that a set of IncRNA in serum can discriminate severe versus mild stages of endometriosis and other associated clinical features. Moreover, the combination of five lncRNAs (NR_038395, NR_038452, ENST00000482343, ENST00000544649, ENST00000393610) is able to discriminate patients with and without endometriosis [116]. In Table 5, we show the list of significant lncRNAs deregulated in endometriosis and the relative references.

Table 5. IncRNAs differentially expressed in Endometriosis patients.

\begin{tabular}{cccc}
\hline IncRNAs & Expression & Sample & Reference \\
\hline AC068282.3 & up & endometrium & {$[117]$} \\
ENST00000393610 & up & serum & {$[116]$} \\
ENST00000465368 & down & serum & {$[116]$} \\
ENST00000482343 & down & serum & {$[116]$} \\
ENST00000529000 & down & serum & {$[116]$} \\
ENST00000544649 & down & serum & {$[116]$} \\
H19 & down & endometrium & {$[179]$} \\
MALAT1 & up & endometrium & {$[184]$} \\
NR_033688 & down & serum & {$[116]$} \\
NR_038395 & down & serum & {$[116]$} \\
NR_038452 & up & serum & {$[116]$} \\
RP11-403H13.1 & down & endometrium & {$[117]$} \\
\hline
\end{tabular}

\section{5. ncRNAs and Chronic Endometritis}

\subsection{Chronic Endometritis}

Chronic Endometritis (CE) is a chronic inflammation of the endometrium that is difficult to diagnose, caused by microbial infection sustained by common bacteria such as Escherichia coli, Enterococcus faecalis and Streptococcus agalactiae $[185,186]$. It has vague symptoms, such as abnormal uterine bleeding, pelvic pain and leukorrhea and, at the moment, hysteroscopy represents the most reliable diagnostic method $[187,188]$. In spite of the benign prognosis, this pathology can impair endometrial receptivity, in spontaneous and in IVF cycles $[189,190]$. Moreover, there are evidences showing that $\mathrm{CE}$ could be a cause of natural preterm labour, premature birth and recurrent miscarriages $[188,191]$. To date, the molecular mechanisms with which CE can cause infertility still remain unknown.

In a paper published by our group in 2013, we demonstrated the altered endometrial expression of genes, involved in inflammatory response, proliferation and apoptosis in CE. These findings are in agreement with literature data, showing that the endometrium of $\mathrm{CE}$ women results an unusual local microenvironment, due to an altered secretion of paracrine factors [192-194]. Accordingly, endometrial receptivity may be impaired as well as proliferative processes may be increased $[195,196]$. 


\section{2. miRNAs and Chronic Endometritis}

At the moment, very few data are present in the literature about the alteration of molecular pathways associated with CE. In spite of CE is considered a mild pathology, it is related to infertility and it has been suggested the association between $\mathrm{CE}$ and endometriosis and between $\mathrm{CE}$ and the endometrial micro-polyps $[193,195]$. Therefore, to investigate the alteration of molecular mechanisms caused by a chronic infection could be interesting.

We showed, for the first time, an up-regulation of miR-27a-3p and miR-124-3p in the endometrium from women affected by $\mathrm{CE}$ and demonstrated their ability to discriminate CE women when the 2 miRNAs were analysed together in the serum [197]. Previously, miR-27a has been found highly expressed in cows with subclinical endometritis [198]. Finally, we found that miR-27a up-regulation is significantly related to IGF1 down-regulation in the same endometrial samples [197]. Proper IGF1 levels are required for successful embryonic and placental development; consequently, the down-regulation of protein could be associated with endometrial quality and with infertility observed in women with CE [199]. Interestingly, miR-27a and miR-27b, two isoforms of the miR-27 family, seem to be involved in different endometrial pathologies. Their up-regulation in endometrium and serum has been described in EC, in endometriosis and in CE $[56,166,197]$ (Figure 3). It would be attractive to demonstrate, by functional experiments, its ability to regulate IGF1 and other messengers, in order to understand its role in endometrial physiopathology and evaluate its prognostic potential and the possibility to plan specific therapy based on RNA interference.

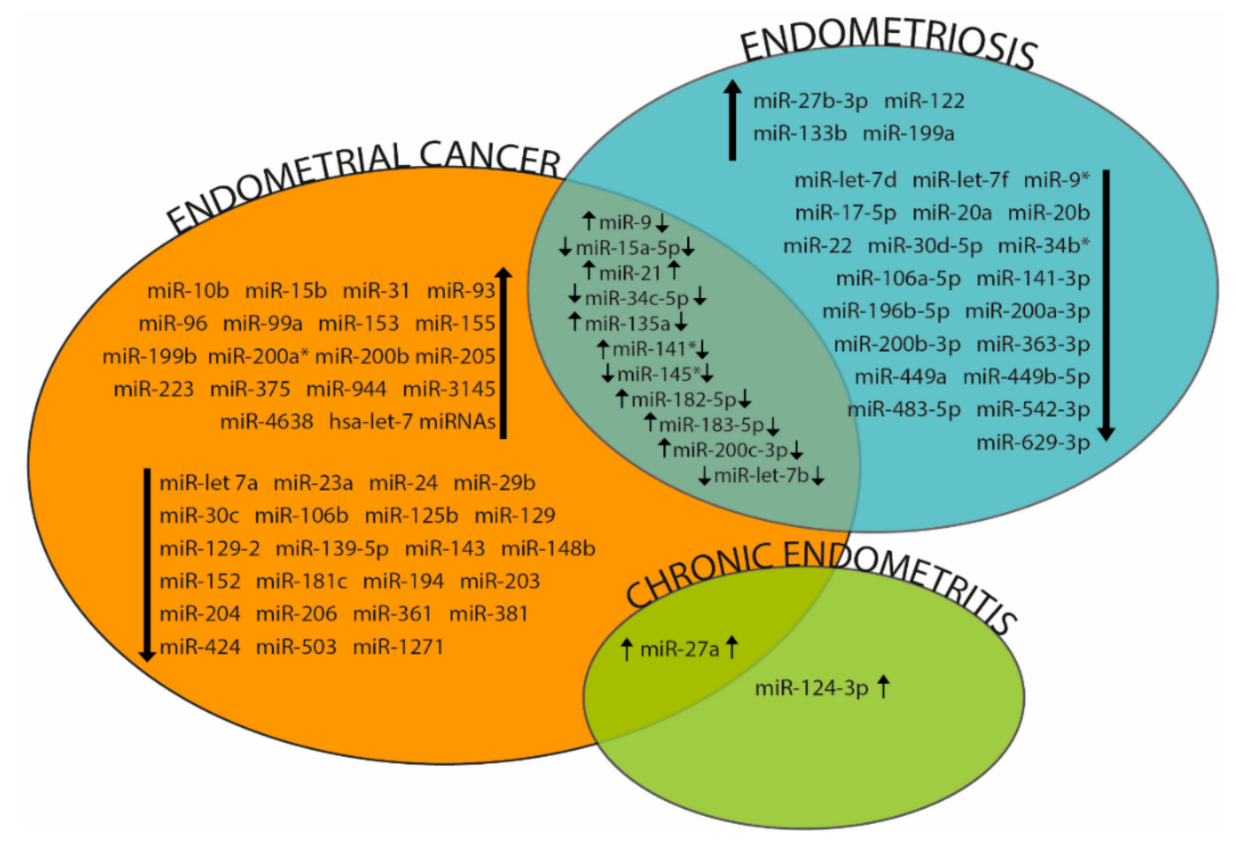

Figure 3. Representative miRNAs involved in endometrial pathologies.

Literature analysis revealed that there are no data about lncRNAs in CE (Figure 4). The overlapping among lncRNAs involved in EC and Endometriosis showed that MALAT1 and H19 are shared across the two pathologies, even if, they show a different trend of expression (Figure 4).

Venn diagram summarizing deregulated miRNAs identified in Endometrial Cancer, Endometriosis and Chronic Endometritis. Intersection areas show molecules differentially expressed in more than one pathology. Up and down-regulated miRNA expression is indicated by black arrows.

Venn diagram summarizing deregulated lncRNAs identified in Endometrial Cancer and Endometriosis. Intersection areas show molecules differentially expressed in more than one pathology. Up and down-regulated lncRNA expression is indicated by black arrows. 


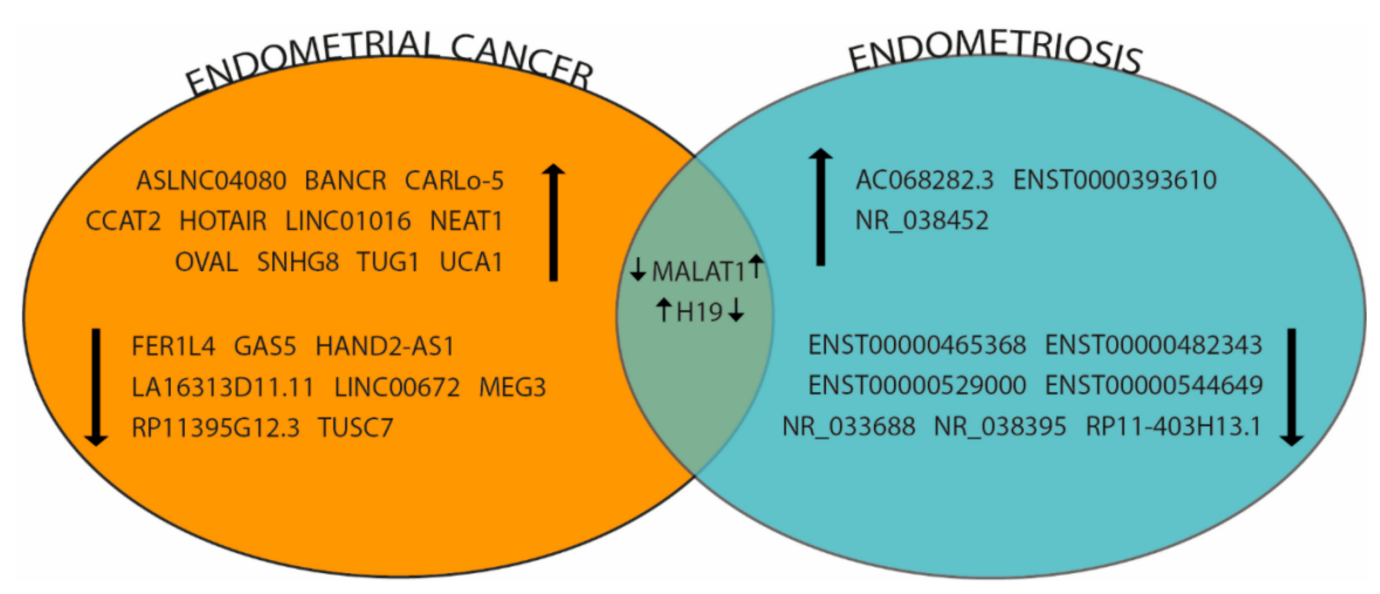

Figure 4. Representative lncRNAs involved in endometrial pathologies.

\section{Conclusions}

The discovery of ncRNAs in the regulation of gene expression inside the pathway from genotype (DNA) to phenotype (Proteins) has deeply transformed contemporary biomedicine. The countless studies on pathogenesis of tumours and complex phenotypes revealed the involvement of ncRNAs in different human diseases and postulated their role as molecular biomarkers in diagnosis, prognosis and also as possible therapeutic targets. In this review, we reported that several ncRNAs are involved in endometrial physiology and that their altered expression can be related to different endometrial disorders. High-throughput techniques are able to give a general overview, discovering many molecules involved in a specific biological pathway. Nevertheless, the complexity of ncRNA networks makes difficult to understand if deregulation of specific molecules represents the etiological cause of a disease or, alternatively, a secondary effect, depending on the perturbation of physiological pathways. Even if, EC, endometriosis and CE are dissimilar endometrial disorders, an association among them could be supposed. Comparing literature data, we detected ncRNAs found dysregulated in the three pathologies (Figures 3 and 4). For some of them, there is no expression concordance between EC and Endometriosis, probably due to the different regulated targets but interestingly 4 miRNAs show the same expression trends and the up-regulation of miR-27 family seems to be involved also in CE. We believe that in order to understand and resolve particular biomedical problems, it would be appropriate to focus on a limited number of molecules to perform functional analyses, in vitro and in vivo on animals.

Author Contributions: A.L.F., F.A. and R.B. have revised the literature, draft the manuscript and prepared Figures and Tables. S.C., A.C. and M.P. have revised the manuscript. C.D.P. conceived and designed the review, written and revised the manuscript. All authors read and approved the manuscript.

Acknowledgments: The authors would like to thank the Scientific Bureau of the University of Catania for language support.

Conflicts of Interest: The authors declared no conflict of interest.

\section{References}

1. Nowak, R. Mining treasures from 'junk DNA'. Science 1994, 263, 608-610. [CrossRef] [PubMed]

2. Lander, E.S.; Linton, L.M.; Birren, B.; Nusbaum, C.; Zody, M.C.; Baldwin, J.; Devon, K.; Dewar, K.; Doyle, M.; FitzHugh, W.; et al. Initial sequencing and analysis of the human genome. Nature 2001, 409, 860-921. [CrossRef] [PubMed]

3. International Human Genome Sequencing Consortium. Finishing the euchromatic sequence of the human genome. Nature 2004, 431, 931-945.

4. Friedman, R.C.; Farh, K.K.; Burge, C.B.; Bartel, D.P. Most mammalian mRNAs are conserved targets of microRNAs. Genome Res. 2009, 19, 92-105. [CrossRef] [PubMed] 
5. Wilczynska, A.; Bushell, M. The complexity of miRNA-mediated repression. Cell Death Differ. 2015, 22, 22-33. [CrossRef] [PubMed]

6. Lee, R.C.; Feinbaum, R.L.; Ambros, V. The C. elegans heterochronic gene lin-4 encodes small RNAs with antisense complementarity to lin-14. Cell 1993, 75, 843-854. [CrossRef]

7. Bartel, D.P. MicroRNAs: Genomics, biogenesis, mechanism and function. Cell 2004, 116, 281-297. [CrossRef]

8. Ragusa, M.; Barbagallo, C.; Statello, L.; Condorelli, A.G.; Battaglia, R.; Tamburello, L.; Barbagallo, D.; Di Pietro, C.; Purrello, M. Non-coding landscapes of colorectal cancer. World J. Gastroenterol. 2015, 21, 11709-11739. [CrossRef] [PubMed]

9. Rosa, A.; Ballarino, M. Long Noncoding RNA Regulation of Pluripotency. Stem Cells Int. 2016, 2016, 1797692. [CrossRef] [PubMed]

10. Fatica, A.; Bozzoni, I. Long non-coding RNAs: New players in cell differentiation and development. Nat. Rev. Genet. 2014, 15, 7-21. [CrossRef] [PubMed]

11. Kitagawa, M.; Kitagawa, K.; Kotake, Y.; Niida, H.; Ohhata, T. Cell cycle regulation by long non-coding RNAs. Cell Mol. Life Sci. 2013, 70, 4785-4794. [CrossRef] [PubMed]

12. Su, Y.; Wu, H.; Pavlosky, A.; Zou, L.L.; Deng, X.; Zhang, Z.X.; Jevnikar, A.M. Regulatory non-coding RNA: New instruments in the orchestration of cell death. Cell Death Dis. 2016, 7, e2333. [CrossRef] [PubMed]

13. Liu, J.; Liu, T.; Wang, X.; He, A. Circles reshaping the RNA world: From waste to treasure. Mol. Cancer 2017, 16, 58. [CrossRef] [PubMed]

14. Hansen, T.B.; Jensen, T.I.; Clausen, B.H.; Bramsen, J.B.; Finsen, B.; Damgaard, C.K.; Kjems, J. Natural RNA circles function as efficient microRNA sponges. Nature 2013, 495, 384-388. [CrossRef] [PubMed]

15. Ragusa, M.; Barbagallo, C.; Brex, D.; Caponnetto, A.; Cirnigliaro, M.; Battaglia, R.; Barbagallo, D.; Di Pietro, C.; Purrello, M. Molecular Crosstalking among Noncoding RNAs: A New Network Layer of Genome Regulation in Cancer. Int. J. Genom. 2017, 2017, 4723193. [CrossRef] [PubMed]

16. Koot, Y.E.; Macklon, N.S. Embryo implantation: Biology, evaluation and enhancement. Curr. Opin. Obstet. Gynecol. 2013, 25, 274-279. [CrossRef] [PubMed]

17. Von Grothusen, C.; Lalitkumar, S.; Boggavarapu, N.R.; Gemzell-Danielsson, K.; Lalitkumar, P.G. Recent advances in understanding endometrial receptivity: Molecular basis and clinical applications. Am. J. Reprod. Immunol. 2014, 72, 148-157. [CrossRef] [PubMed]

18. Galliano, D.; Pellicer, A. MicroRNA and implantation. Fertil. Steril. 2014, 101, 1531-1544. [CrossRef] [PubMed]

19. Díaz-Gimeno, P.; Horcajadas, J.A.; Martínez-Conejero, J.A. A genomic diagnostic tool for human endometrial receptivity based on the transcriptomic signature. Fertil. Steril. 2011, 95, 50-60. [CrossRef] [PubMed]

20. Díaz-Gimeno, P.; Ruiz-Alonso, M.; Blesa, D.; Bosch, N.; Martínez-Conejero, J.A.; Alamá, P.; Garrido, N.; Pellicer, A.; Simón, C. The accuracy and reproducibility of the endometrial receptivity array is superior to histology as a diagnostic method for endometrial receptivity. Fertil. Steril. 2013, 99, 508-517. [CrossRef] [PubMed]

21. Garrido-Gòmez, T.; Ruiz-Alonso, M.; Blesa, D.; Diaz-Gimeno, P.; Vilella, F.; Simòn, C. Profiling the gene signature of endometrial receptivity: Clinical results. Fertil. Steril. 2013, 99, 1078-1085. [CrossRef] [PubMed]

22. Ruiz-Alonso, M.; Blesa, D.; Díaz-Gimeno, P.; Gómez, E.; Fernández-Sánchez, M.; Carranza, F.; Carrera, J.; Vilella, F.; Pellicer, A.; Simón, C. The endometrial receptivity array for diagnosis and personalized embryo transfer as a treatment for patients with repeated implantation failure. Fertil. Steril. 2013, 100, 818-824. [CrossRef] [PubMed]

23. Inyawilert, W.; TY, F.; Lin, C.T.; Tang, P.C. Let-7-mediated suppression of mucin 1 expression in the mouse uterus during embryo implantation. J. Reprod. Dev. 2015, 61, 138-144. [CrossRef] [PubMed]

24. Altmäe, S.; Martinez-Conejero, J.A.; Esteban, F.J.; Ruiz-Alonso, M.; Stavreus-Evers, A.; Horcajadas, J.A.; Salumets, A. MicroRNAs miR-30b, miR-30d and miR-494 regulate human endometrial receptivity. Reprod. Sci. 2013, 20, 308-317. [CrossRef] [PubMed]

25. Inyawilert, W.; TY, F.; Lin, C.T.; Tang, P.C. MicroRNA-199a mediates mucin 1 expression in mouse uterus during implantation. Reprod. Fertil. Dev. 2014, 26, 653-664. [CrossRef] [PubMed]

26. Kang, Y.J.; Lees, M.; Matthews, L.C.; Kimber, S.J.; Forbes, K.; Aplin, J.D. MiR-145 suppresses embryo-epithelial juxtacrine communication at implantation by modulating maternal IGF1R. J. Cell Sci. 2015, 128, 804-814. [CrossRef] [PubMed] 
27. Liang, J.; Wang, S.; Wang, Z. Role of microRNAs in embryo implantation. Reprod. Biol. Endocrinol. 2017, 15, 90. [CrossRef] [PubMed]

28. Li, Z.; Gou, J.; Jia, J.; Zhao, X. MicroRNA-429 functions as a regulator of epithelial-mesenchymal transition by targeting Pcdh8 during murine embryo implantation. Hum. Reprod. 2015, 30, 507-518. [CrossRef] [PubMed]

29. Li, Z.; Jia, J.; Gou, J.; Tong, A.; Liu, X.; Zhao, X.; Yi, T. Mmu-miR-126a-3p plays a role in murine embryo implantation by regulating Itga11. Reprod. Biomed. Online 2015, 31, 384-393. [CrossRef] [PubMed]

30. Chen, C.; Zhao, Y.; Yu, Y.; Li, R.; Qiao, J. MiR-125b regulates endometrial receptivity by targeting MMP26 in women undergoing IVF-ET with elevated progesterone on HCG priming day. Sci. Rep. 2016, 6, 25302. [CrossRef] [PubMed]

31. Cha, J.; Sun, X.; Dey, S.K. Mechanisms of implantation: Strategies for successful pregnancy. Nat. Med. 2012, 18, 1754-1767. [CrossRef] [PubMed]

32. Vilella, F.; Moreno-Moya, J.M.; Balaguer, N.; Grasso, A.; Herrero, M.; Martínez, S.; Marcilla, A.; Simón, C. Hsa-miR-30d, secreted by the human endometrium, is taken up by the pre-implantation embryo and might modify its transcriptome. Development 2015, 142, 3210-3221. [CrossRef] [PubMed]

33. Giacomini, E.; Vago, R.; Sanchez, A.M.; Podini, P.; Zarovni, N.; Murdica, V.; Rizzo, R.; Bortolotti, D.; Candiani, M.; Viganò, P. Secretome of in vitro cultured human embryos contains extracellular vesicles that are uptaken by the maternal side. Sci. Rep. 2017, 7, 5210. [CrossRef] [PubMed]

34. Ng, Y.H.; Rome, S.; Jalabert, A.; Forterre, A.; Singh, H.; Hincks, C.L.; Salamonsen, L.A. Endometrial exosomes/microvesicles in the uterine microenvironment: A new paradigm for embryo-endometrial cross talk at implantation. PLoS ONE. 2013, 8, e58502. [CrossRef] [PubMed]

35. Bendifallah, S.; Ouldamer, L.; Lavoue, V.; Canlorbe, G.; Raimond, E.; Coutant, C.; Graesslin, O.; Touboul, C.; Collinet, P.; Daraï, E.; et al. Patterns of recurrence and outcomes in surgically treated women with endometrial cancer according to ESMO-ESGO-ESTRO Consensus Conference risk groups: Results from the FRANCOGYN study Group. Gynecol. Oncol. 2017, 144, 107-112. [CrossRef] [PubMed]

36. Bokhman, J.V. Two pathogenetic types of endometrial carcinoma. Gynecol. Oncol. 1983, 15, 10-17. [CrossRef]

37. Rose, P.G. Endometrial carcinoma. N. Engl. J. Med. 1997, 336, 1335. [CrossRef] [PubMed]

38. Sherman, M.E.; Sturgeon, S.; Brinton, L.; Kurman, R.J. Endometrial cancer chemoprevention: Implications of diverse pathways of carcinogenesis. J. Cell Biochem. Suppl. 1995, 23, 160-164. [CrossRef] [PubMed]

39. Mutter, G.L.; Lin, M.C.; Fitzgerald, J.T.; Kum, J.B.; Baak, J.P.; Lees, J.A.; Weng, L.P.; Eng, C. Altered PTEN expression as a diagnostic marker for the earliest endometrial precancers. J. Natl. Cancer Inst. 2000, 92, 924-930. [CrossRef] [PubMed]

40. Furness, S.; Roberts, H.; Marjoribanks, J.; Lethaby, A.; Hickey, M.; Farquhar, C. Hormone therapy in postmenopausal women and risk of endometrial hyperplasia. Cochrane Database Syst. Rev. 2009, 2, CD000402. [CrossRef]

41. Hecht, J.L.; Mutter, G.L. Molecular and pathologic aspects of endometrial carcinogenesis. J. Clin. Oncol. 2006, 24, 4783-4791. [CrossRef] [PubMed]

42. Lax, S.F.; Kendall, B.; Tashiro, H.; Slebos, R.J.; Hedrick, L. The frequency of p53, K-ras mutations and microsatellite instability differs in uterine endometrioid and serous carcinoma: Evidence of distinct molecular genetic pathways. Cancer 2000, 88, 814-824. [CrossRef]

43. Zagouri, F.; Bozas, G.; Kafantari, E.; Tsiatas, M.; Nikitas, N.; Dimopoulos, M.A.; Papadimitriou, C.A. Endometrial cancer: What is new in adjuvant and molecularly targeted therapy? Obstet. Gynecol. Int. 2010, 2010, 749579. [CrossRef] [PubMed]

44. Vallone, C.; Rigon, G.; Gulia, C.; Baffa, A.; Votino, R.; Morosetti, G.; Zaami, S.; Briganti, V.; Catania, F.; Gaffi, M.; et al. Non-Coding RNAs and Endometrial Cancer. Genes 2018, 9, 187. [CrossRef] [PubMed]

45. Klinge, C.M. Non-coding RNAs: Long non-coding RNAs and microRNAs in endocrine-related cancers. Endocr. Relat. Cancer 2018, 25, R259-R282. [CrossRef] [PubMed]

46. Smolle, M.A.; Bullock, M.D.; Ling, H.; Pichler, M.; Haybaeck, J. Long Non-Coding RNAs in Endometrial Carcinoma. Int. J. Mol. Sci. 2015, 16, 26463-26472. [CrossRef] [PubMed]

47. Vasilatou, D.; Sioulas, V.D.; Pappa, V.; Papageorgiou, S.G.; Vlahos, N.F. The role of miRNAs in endometrial cancer. Epigenomics 2015, 7, 951-959. [CrossRef] [PubMed] 
48. Martelli, A.M.; Evangelisti, C.; Chiarini, F.; Grimaldi, C.; Cappellini, A.; Ognibene, A.; McCubrey, J.A. The emerging role of the phosphatidylinositol 3-kinase/Akt/mammalian target of rapamycin signaling network in normal myelopoiesis and leukemogenesis. Biochim. Biophys. Acta 2010, 1803, 991-1002. [CrossRef] [PubMed]

49. Djordjevic, B.; Hennessy, B.T.; Li, J.; Barkoh, B.A.; Luthra, R.; Mills, G.B.; Broaddus, R.R. Clinical assessment of PTEN loss in endometrial carcinoma: Immunohistochemistry out-performs gene sequencing. Mod. Pathol. 2012, 25, 699-708. [CrossRef] [PubMed]

50. Zhang, G.; Hou, X.; Li, Y.; Zhao, M. MiR-205 inhibits cell apoptosis by targeting phosphatase and tensin homolog deleted on chromosome ten in endometrial cancer Ishikawa cells. BMC Cancer 2014, 14, 440. [CrossRef] [PubMed]

51. Jin, C.; Liang, R. miR-205 promotes epithelial-mesenchymal transition by targeting AKT signaling in endometrial cancer cells. J. Obstet. Gynaecol. Res. 2015, 41, 1653-1660. [CrossRef] [PubMed]

52. Torres, A.; Kozak, J.; Korolczuk, A.; Rycak, D.; Wdowiak, P.; Maciejewski, R.; Torres, K. Locked nucleic acid-inhibitor of miR-205 decreases endometrial cancer cells proliferation in vitro and in vivo. Oncotarget 2016, 7, 73651-73663. [CrossRef] [PubMed]

53. Qin, X.; Yan, L.; Zhao, X.; Li, C.; Fu, Y. microrna-21 overexpression contributes to cell proliferation by targeting PTEN in endometrioid endometrial cancer. Oncol. Lett. 2012, 4, 1290-1296. [CrossRef] [PubMed]

54. Goto, T.; Takano, M.; Albergaria, A.; Briese, J.; Pomeranz, K.M.; Cloke, B.; Fusi, L.; Feroze-Zaidi, F.; Maywald, N.; Sajin, M.; et al. Mechanism and functional consequences of loss of FOXO1 expression in endometrioid endometrial cancer cells. Oncogene 2008, 27, 9-19. [CrossRef] [PubMed]

55. Kajihara, T.; Brosens, J.J.; Ishihara, O. The role of FOXO1 in the decidual transformation of the endometrium and early pregnancy. Med. Mol. Morphol. 2013, 46, 61-68. [CrossRef] [PubMed]

56. Myatt, S.S.; Wang, J.; Monteiro, L.J.; Christian, M.; Ho, K.K.; Fusi, L.; Dina, R.E.; Brosens, J.J.; Ghaem-Maghami, S.; Lam, E.W. Definition of microRNAs that repress expression of the tumor suppressor gene FOXO1 in endometrial cancer. Cancer Res. 2010, 70, 367-377. [CrossRef] [PubMed]

57. Chung, T.K.; Lau, T.S.; Cheung, T.H.; Yim, S.F.; Lo, K.W.; Siu, N.S.; Chan, L.K.; Yu, M.Y.; Kwong, J.; Doran, G.; et al. Dysregulation of microRNA-204 mediates migration and invasion of endometrial cancer by regulating FOXC1. Int. J. Cancer 2012, 130, 1036-1045. [CrossRef] [PubMed]

58. Xia, Y.; Zhu, Y.; Ma, T.; Pan, C.; Wang, J.; He, Z.; Li, Z.; Qi, X.; Chen, Y. miR-204 functions as a tumor suppressor by regulating SIX1 in NSCLC. FEBS Lett. 2014, 588, 3703-3712. [CrossRef] [PubMed]

59. Lam, E.K.; Wang, X.; Shin, V.Y.; Zhang, S.; Morrison, H.; Sun, J.; Ng, E.K.; Yu, J.; Jin, H. A microRNA contribution to aberrant Ras activation in gastric cancer. Am. J. Transl. Res. 2011, 3, 209-218. [PubMed]

60. Manning, B.D.; Cantley, L.C. AKT/PKB signaling: Navigating downstream. Cell 2007, 129, 1261-1274. [CrossRef] [PubMed]

61. Zhang, R.; He, Y.; Zhang, X.; Xing, B.; Sheng, Y.; Lu, H.; Wei, Z. Estrogen receptor-regulated microRNAs contribute to the BCL2/BAX imbalance in endometrial adenocarcinoma and precancerous lesions. Cancer Lett. 2012, 314, 155-165. [CrossRef] [PubMed]

62. Backes, F.J.; Walker, C.J.; Goodfellow, P.J.; Hade, E.M.; Agarwal, G.; Mutch, D.; Cohn, D.E.; Suarez, A.A. Estrogen receptor-alpha as a predictive biomarker in endometrioid endometrial cancer. Gynecol. Oncol. 2016, 141, 312-317. [CrossRef] [PubMed]

63. Lebeau, A.; Grob, T.; Holst, F.; Seyedi-Fazlollahi, N.; Moch, H.; Terracciano, L.; Turzynski, A.; Choschzick, M.; Sauter, G.; Simon, R. Oestrogen receptor gene (ESR1) amplification is frequent in endometrial carcinoma and its precursor lesions. J. Pathol. 2008, 216, 151-157. [CrossRef] [PubMed]

64. Jongen, V.; Briët, J.; de Jong, R.; ten Hoor, K.; Boezen, M.; van der Zee, A.; Nijman, H.; Hollema, H. Expression of estrogen receptor-alpha and -beta and progesterone receptor- $\mathrm{A}$ and $-\mathrm{B}$ in a large cohort of patients with endometrioid endometrial cancer. Gynecol. Oncol. 2009, 112, 537-542. [CrossRef] [PubMed]

65. Tan, D.S.; Lambros, M.B.; Marchiò, C.; Reis-Filho, J.S. ESR1 amplification in endometrial carcinomas: Hope or hyperbole? J. Pathol. 2008, 216, 271-274. [CrossRef] [PubMed]

66. Chen, X.; Yan, Q.; Li, S.; Zhou, L.; Yang, H.; Yang, Y.; Liu, X.; Wan, X. Expression of the tumor suppressor miR-206 is associated with cellular proliferative inhibition and impairs invasion in ER $\alpha$-positive endometrioid adenocarcinoma. Cancer Lett. 2012, 314, 41-53. [CrossRef] [PubMed] 
67. O'Leary, N.A.; Wright, M.W.; Brister, J.R.; Ciufo, S.; Haddad, D.; McVeigh, R.; Rajput, B.; Robbertse, B.; Smith-White, B.; Ako-Adjei, D.; et al. Reference sequence (RefSeq) database at NCBI: Current status, taxonomic expansion and functional annotation. Nucleic Acids Res. 2016, 44, D733-D745. [CrossRef] [PubMed]

68. Pengchong, H.; Tao, H. Expression of IGF-1R, VEGF-C and D2-40 and their correlation with lymph node metastasis in endometrial adenocarcinoma. Eur. J. Gynaecol. Oncol. 2011, 32, 660-664. [PubMed]

69. Tu, C.; Wang, F.; Wan, J. MicroRNA-381 inhibits cell proliferation and invasion in endometrial carcinoma by targeting the IGF-1R. Mol. Med. Rep. 2018, 17, 4090-4098. [CrossRef] [PubMed]

70. Banno, K.; Kisu, I.; Yanokura, M.; Masuda, K.; Ueki, A.; Kobayashi, Y.; Susumu, N.; Aoki, D. Epigenetics and genetics in endometrial cancer: New carcinogenic mechanisms and relationship with clinical practice. Epigenomics 2012, 4, 147-162. [CrossRef] [PubMed]

71. Tao, M.H.; Freudenheim, J.L. DNA methylation in endometrial cancer. Epigenetics 2010, 5, 491-498. [CrossRef] [PubMed]

72. Huang, Y.W.; Liu, J.C.; Deatherage, D.E.; Luo, J.; Mutch, D.G.; Goodfellow, P.J.; Miller, D.S.; Huang, T.H. Epigenetic repression of microRNA-129-2 leads to overexpression of SOX4 oncogene in endometrial cancer. Cancer Res. 2009, 69, 9038-9046. [CrossRef] [PubMed]

73. Zighelboim, I.; Goodfellow, P.J.; Gao, F.; Gibb, R.K.; Powell, M.A.; Rader, J.S.; Mutch, D.G. Microsatellite instability and epigenetic inactivation of MLH1 and outcome of patients with endometrial carcinomas of the endometrioid type. J. Clin. Oncol. 2007, 25, 2042-2048. [CrossRef] [PubMed]

74. Bueno, M.J.; Pérez de Castro, I.; Gómez de Cedrón, M.; Santos, J.; Calin, G.A.; Cigudosa, J.C.; Croce, C.M.; Fernández-Piqueras, J.; Malumbres, M. Genetic and epigenetic silencing of microRNA-203 enhances ABL1 and BCR-ABL1 oncogene expression. Cancer Cell 2008, 13, 496-506. [CrossRef] [PubMed]

75. Huang, Y.W.; Kuo, C.T.; Chen, J.H.; Goodfellow, P.J.; Huang, T.H.; Rader, J.S.; Uyar, D.S. Hypermethylation of miR-203 in endometrial carcinomas. Gynecol. Oncol. 2014, 133, 340-345. [CrossRef] [PubMed]

76. Xie, D.; Liang, Y.; Su, Y.; An, Y.; Qu, P. miR-152 inhibits proliferation of human endometrial cancer cells via inducing G2/M phase arrest by suppressing CDC25B expression. Biomed. Pharmacother. 2018, 99, $299-305$. [CrossRef] [PubMed]

77. Tsuruta, T.; Kozaki, K.; Uesugi, A.; Furuta, M.; Hirasawa, A.; Imoto, I.; Susumu, N.; Aoki, D.; Inazawa, J. miR-152 is a tumor suppressor microRNA that is silenced by DNA hypermethylation in endometrial cancer. Cancer Res. 2011, 71, 6450-6462. [CrossRef] [PubMed]

78. Kraljevic Pavelic, S.; Sedic, M.; Bosnjak, H.; Spaventi, S.; Pavelic, K. Metastasis: New perspectives on an old problem. Mol. Cancer 2011, 10, 22. [CrossRef] [PubMed]

79. Chen, S.; Chen, X.; Sun, K.X.; Xiu, Y.L.; Liu, B.L.; Feng, M.X.; Sang, X.B.; Zhao, Y. MicroRNA-93 Promotes Epithelial-Mesenchymal Transition of Endometrial Carcinoma Cells. PLoS ONE 2016, 11, e0165776. [CrossRef] [PubMed]

80. Wang, J.; Bao, W.; Qiu, M.; Liao, Y.; Che, Q.; Yang, T.; He, X.; Qiu, H.; Wan, X. Forkhead-box A1 suppresses the progression of endometrial cancer via crosstalk with estrogen receptor $\alpha$. Oncol. Rep. 2014, 31, 1225-1234. [CrossRef] [PubMed]

81. Zhou, H.; Xu, X.; Xun, Q.; Yu, D.; Ling, J.; Guo, F.; Yan, Y.; Shi, J.; Hu, Y. microRNA-30c negatively regulates endometrial cancer cells by targeting metastasis-associated gene-1. Oncol. Rep. 2012, 27, 807-812. [CrossRef] [PubMed]

82. Kong, X.; Xu, X.; Yan, Y.; Guo, F.; Li, J.; Hu, Y.; Zhou, H.; Xun, Q. Estrogen regulates the tumour suppressor MiRNA-30c and its target gene, MTA-1, in endometrial cancer. PLoS ONE 2014, 9, e90810. [CrossRef] [PubMed]

83. Dong, P.; Kaneuchi, M.; Watari, H.; Sudo, S.; Sakuragi, N. MicroRNA-106b modulates epithelial-mesenchymal transition by targeting TWIST1 in invasive endometrial cancer cell lines. Mol. Carcinog. 2014, 53, 349-359. [CrossRef] [PubMed]

84. Qin, Q.; Xu, Y.; He, T.; Qin, C.; Xu, J. Normal and disease-related biological functions of Twist1 and underlying molecular mechanisms. Cell Res. 2012, 22, 90-106. [CrossRef] [PubMed]

85. Tan, Z.Q.; Liu, F.X.; Tang, H.L.; Su, Q. Expression and its clinical significance of hsa-miR-155 in serum of endometrial cancer. Zhonghua Fu Chan Ke Za Zhi 2010, 45, 772-774. [PubMed] 
86. Torres, A.; Torres, K.; Pesci, A.; Ceccaroni, M.; Paszkowski, T.; Cassandrini, P.; Zamboni, G.; Maciejewski, R. Deregulation of miR-100, miR-99a and miR-199b in tissues and plasma coexists with increased expression of mTOR kinase in endometrioid endometrial carcinoma. BMC Cancer 2012, 12, 369. [CrossRef] [PubMed]

87. Wang, H.; Wang, T.T.; Lv, X.P. Expression and prognostic value of miRNA-29b in peripheral blood for endometrial cancer. Future Oncol. 2018, 14. [CrossRef] [PubMed]

88. Wang, L.; Chen, Y.J.; Xu, K.; Xu, H.; Shen, X.Z.; Tu, R.Q. Circulating microRNAs as a fingerprint for endometrial endometrioid adenocarcinoma. PLoS ONE 2014, 9, e110767. [CrossRef] [PubMed]

89. Liu, P.; Qi, M.; Ma, C.; Lao, G.; Liu, Y.; Liu, Y.; Liu, Y. Let7a inhibits the growth of endometrial carcinoma cells by targeting Aurora-B. FEBS Lett. 2013, 587, 2523-2529. [CrossRef] [PubMed]

90. Ihira, K.; Dong, P.; Xiong, Y.; Watari, H.; Konno, Y.; Hanley, S.J.; Noguchi, M.; Hirata, N.; Suizu, F.; Yamada, T.; et al. EZH2 inhibition suppresses endometrial cancer progression via miR-361/Twist axis. Oncotarget 2017, 8, 13509-13520. [CrossRef] [PubMed]

91. Chen, H.; Fan, Y.; Xu, W.; Chen, J.; Xu, C.; Wei, X.; Fang, D.; Feng, Y. miR-10b Inhibits Apoptosis and Promotes Proliferation and Invasion of Endometrial Cancer Cells via Targeting HOXB3. Cancer Biother. Radiopharm. 2016, 31, 225-231. [CrossRef] [PubMed]

92. Wang, Z.M.; Wan, X.H.; Sang, G.Y.; Zhao, J.D.; Zhu, Q.Y.; Wang, D.M. miR-15a-5p suppresses endometrial cancer cell growth via Wnt/ $\beta$-catenin signaling pathway by inhibiting WNT3A. Eur. Rev. Med. Pharmacol. Sci. 2017, 21, 4810-4818. [PubMed]

93. Liu, P.; Wang, C.; Ma, C.; Wu, Q.; Zhang, W.; Lao, G. MicroRNA-23a regulates epithelial-to-mesenchymal transition in endometrial endometrioid adenocarcinoma by targeting SMAD3. Cancer Cell Int. 2016, 16, 67. [CrossRef] [PubMed]

94. Lang, B.; Shang, C.; Meng, L. Targeted Silencing of S100A8 Gene by miR-24 to Increase Chemotherapy Sensitivity of Endometrial Carcinoma Cells to Paclitaxel. Med. Sci. Monit. 2016, 22, 1953-1958. [CrossRef] [PubMed]

95. Chen, H.X.; Xu, X.X.; Tan, B.Z.; Zhang, Z.; Zhou, X.D. MicroRNA-29b Inhibits Angiogenesis by Targeting VEGFA through the MAPK/ERK and PI3K/Akt Signaling Pathways in Endometrial Carcinoma. Cell Physiol. Biochem. 2017, 41, 933-946. [CrossRef] [PubMed]

96. Mitamura, T.; Watari, H.; Wang, L.; Kanno, H.; Kitagawa, M.; Hassan, M.K.; Kimura, T.; Tanino, M.; Nishihara, H.; Tanaka, S.; et al. microRNA 31 functions as an endometrial cancer oncogene by suppressing Hippo tumor suppressor pathway. Mol. Cancer. 2014, 13, 97. [CrossRef] [PubMed]

97. Jiang, L.; Meng, W.; Zeng, J.; Hu, H.; Lu, L. MiR-34c oligonucleotide enhances chemosensitivity of Ishikawa cell to cisplatin by inducing apoptosis. Cell Biol. Int. 2013, 37, 577-583. [CrossRef] [PubMed]

98. Shang, C.; Lu, Y.M.; Meng, L.R. MicroRNA-125b down-regulation mediates endometrial cancer invasion by targeting ERBB2. Med. Sci. Monit. 2012, 18, BR149-BR155. [CrossRef] [PubMed]

99. Wu, J.; Qian, J.; Li, C.; Kwok, L.; Cheng, F.; Liu, P.; Perdomo, C.; Kotton, D.; Vaziri, C.; Anderlind, C.; et al. miR-129 regulates cell proliferation by downregulating Cdk6 expression. Cell Cycle 2010, 9, 1809-1818. [CrossRef] [PubMed]

100. Chen, J.; Gao, F.; Liu, N. L1CAM promotes epithelial to mesenchymal transition and formation of cancer initiating cells in human endometrial cancer. Exp. Ther. Med. 2018, 15, 2792-2797. [CrossRef] [PubMed]

101. Liu, J.; Li, C.; Jiang, Y.; Wan, Y.; Zhou, S.; Cheng, W. Tumor-suppressor role of miR-139-5p in endometrial cancer. Cancer Cell Int. 2018, 18, 51. [CrossRef] [PubMed]

102. Lee, T.S.; Jeon, H.W.; Kim, Y.B.; Kim, Y.A.; Kim, M.A.; Kang, S.B. Aberrant microRNA expression in endometrial carcinoma using formalin-fixed paraffin-embedded (FFPE) tissues. PLoS ONE 2013, 8, e81421. [CrossRef] [PubMed]

103. Chang, L.; Zhang, D.; Shi, H.; Bian, Y.; Guo, R. miR-143 inhibits endometrial cancer cell proliferation and metastasis by targeting MAPK1. Oncotarget 2017, 8, 84384-84395. [CrossRef] [PubMed]

104. Wang, Y.; Adila, S.; Zhang, X.; Dong, Y.; Li, W.; Zhou, M.; Li, T. MicroRNA expression signature profile and its clinical significance in endometrioid carcinoma. Zhonghua Bing Li Xue Za Zhi 2014, 43, 88-94. [PubMed]

105. Qu, J.; Zhang, L.; Li, L.; Su, Y. miR-148b functions as a tumor suppressor by targeting endoplasmic reticulum metallo protease 1 in human endometrial cancer cells. Oncol. Res. 2018. [CrossRef] [PubMed] 
106. Devor, E.J.; Miecznikowski, J.; Schickling, B.M.; Gonzalez-Bosquet, J.; Lankes, H.A.; Thaker, P.; Argenta, P.A.; Pearl, M.L.; Zweizig, S.L.; Mannel, R.S.; et al. Dysregulation of miR-181c expression influences recurrence of endometrial endometrioid adenocarcinoma by modulating NOTCH2 expression: An NRG Oncology/Gynecologic Oncology Group study. Gynecol. Oncol. 2017, 147, 648-653. [CrossRef] [PubMed]

107. Ruan, H.; Liang, X.; Zhao, W.; Ma, L.; Zhao, Y. The effects of microRNA-183 promots cell proliferation and invasion by targeting MMP-9 in endometrial cancer. Biomed. Pharmacother. 2017, 89, 812-818. [CrossRef] [PubMed]

108. Dong, P.; Kaneuchi, M.; Watari, H.; Hamada, J.; Sudo, S.; Ju, J.; Sakuragi, N. MicroRNA-194 inhibits epithelial to mesenchymal transition of endometrial cancer cells by targeting oncogene BMI-1. Mol. Cancer 2011, 10, 99. [CrossRef] [PubMed]

109. Shi, W.; Wang, X.; Ruan, L.; Fu, J.; Liu, F.; Qu, J. MiR-200a promotes epithelial-mesenchymal transition of endometrial cancer cells by negatively regulating FOXA2 expression. Pharmazie 2017, 72, 694-699. [CrossRef] [PubMed]

110. Snowdon, J.; Zhang, X.; Childs, T.; Tron, V.A.; Feilotter, H. The microRNA-200 family is upregulated in endometrial carcinoma. PLoS ONE 2011, 6, e22828. [CrossRef] [PubMed]

111. Lu, Z.; Nian, Z.; Jingjing, Z.; Tao, L.; Quan, L. MicroRNA-424/E2F6 feedback loop modulates cell invasion, migration and EMT in endometrial carcinoma. Oncotarget 2017, 8, 114281-114291. [CrossRef] [PubMed]

112. Xu, Y.Y.; Wu, H.J.; Ma, H.D.; Xu, L.P.; Huo, Y.; Yin, L.R. MicroRNA-503 suppresses proliferation and cell-cycle progression of endometrioid endometrial cancer by negatively regulating cyclin D1. FEBS J. 2013, 280, 3768-3779. [CrossRef] [PubMed]

113. He, Z.; Xu, H.; Meng, Y.; Kuang, Y. miR-944 acts as a prognostic marker and promotes the tumor progression in endometrial cancer. Biomed. Pharmacother. 2017, 88, 902-910. [CrossRef] [PubMed]

114. Li, L.; Qu, Y.W.; Li, Y.P. Over-expression of miR-1271 inhibits endometrial cancer cells proliferation and induces cell apoptosis by targeting CDK1. Eur. Rev. Med. Pharmacol. Sci. 2017, 21, 2816-2822. [PubMed]

115. Hosseini, E.S.; Meryet-Figuiere, M.; Sabzalipoor, H.; Kashani, H.H.; Nikzad, H.; Asemi, Z. Dysregulated expression of long noncoding RNAs in gynecologic cancers. Mol. Cancer 2017, 16, 107. [CrossRef] [PubMed]

116. Wang, W.T.; Sun, Y.M.; Huang, W.; He, B.; Zhao, Y.N.; Chen, Y.Q. Genome-wide Long Non-coding RNA Analysis Identified Circulating LncRNAs as Novel Non-invasive Diagnostic Biomarkers for Gynecological Disease. Sci. Rep. 2016, 6, 23343. [CrossRef] [PubMed]

117. Wang, Y.; Li, Y.; Yang, Z.; Liu, K.; Wang, D. Genome-Wide Microarray Analysis of Long Non-Coding RNAs in Eutopic Secretory Endometrium with Endometriosis. Cell Physiol. Biochem. 2015, 37, 2231-2245. [CrossRef] [PubMed]

118. Akrami, R.; Jacobsen, A.; Hoell, J.; Schultz, N.; Sander, C.; Larsson, E. Comprehensive analysis of long non-coding RNAs in ovarian cancer reveals global patterns and targeted DNA amplification. PLoS ONE 2013, 8, e80306. [CrossRef] [PubMed]

119. Zhao, Y.; Yang, Y.; Trovik, J.; Sun, K.; Zhou, L.; Jiang, P.; Lau, T.S.; Hoivik, E.A.; Salvesen, H.B.; Sun, H.; et al. A novel wnt regulatory axis in endometrioid endometrial cancer. Cancer Res. 2014, 74, 5103-5117. [CrossRef] [PubMed]

120. Dong, S.; Qu, X.; Li, W.; Zhong, X.; Li, P.; Yang, S.; Chen, X.; Shao, M.; Zhang, L. The long non-coding RNA, GAS5, enhances gefitinib-induced cell death in innate EGFR tyrosine kinase inhibitor-resistant lung adenocarcinoma cells with wide-type EGFR via downregulation of the IGF-1R expression. J. Hematol. Oncol. 2015, 8, 43. [CrossRef] [PubMed]

121. Liu, Z.; Wang, W.; Jiang, J.; Bao, E.; Xu, D.; Zeng, Y.; Tao, L.; Qiu, J. Downregulation of GAS5 promotes bladder cancer cell proliferation, partly by regulating CDK6. PLoS ONE 2013, 8, e73991. [CrossRef] [PubMed]

122. Mourtada-Maarabouni, M.; Pickard, M.R.; Hedge, V.L.; Farzaneh, F.; Williams, G.T. GAS5, a non-protein-coding RNA, controls apoptosis and is downregulated in breast cancer. Oncogene 2009, 28, 195-208. [CrossRef] [PubMed]

123. Sun, M.; Jin, F.Y.; Xia, R.; Kong, R.; Li, J.H.; Xu, T.P.; Liu, Y.W.; Zhang, E.B.; Liu, X.H.; De, W. Decreased expression of long noncoding RNA GAS5 indicates a poor prognosis and promotes cell proliferation in gastric cancer. BMC Cancer 2014, 14, 319. [CrossRef] [PubMed]

124. Tu, Z.Q.; Li, R.J.; Mei, J.Z.; Li, X.H. Down-regulation of long non-coding RNA GAS5 is associated with the prognosis of hepatocellular carcinoma. Int. J. Clin. Exp. Pathol. 2014, 7, 4303-4309. [PubMed] 
125. Guo, C.; Song, W.Q.; Sun, P.; Jin, L.; Dai, H.Y. LncRNA-GAS5 induces PTEN expression through inhibiting miR-103 in endometrial cancer cells. J. Biomed. Sci. 2015, 22, 100. [CrossRef] [PubMed]

126. Gupta, R.A.; Shah, N.; Wang, K.C.; Kim, J.; Horlings, H.M.; Wong, D.J.; Tsai, M.C.; Hung, T.; Argani, P.; Rinn, J.L.; et al. Long non-coding RNA HOTAIR reprograms chromatin state to promote cancer metastasis. Nature 2010, 464, 1071-1076. [CrossRef] [PubMed]

127. He, X.; Bao, W.; Li, X.; Chen, Z.; Che, Q.; Wang, H.; Wan, X.P. The long non-coding RNA HOTAIR is upregulated in endometrial carcinoma and correlates with poor prognosis. Int. J. Mol. Med. 2014, 33, 325-332. [CrossRef] [PubMed]

128. Huang, J.; Ke, P.; Guo, L.; Wang, W.; Tan, H.; Liang, Y.; Yao, S. Lentivirus-mediated RNA interference targeting the long noncoding RNA HOTAIR inhibits proliferation and invasion of endometrial carcinoma cells in vitro and in vivo. Int. J. Gynecol. Cancer 2014, 24, 635-642. [CrossRef] [PubMed]

129. Zemel, S.; Bartolomei, M.S.; Tilghman, S.M. Physical linkage of two mammalian imprinted genes, H19 and insulin-like growth factor 2. Nat. Genet. 1992, 2, 61-65. [CrossRef] [PubMed]

130. Cui, H.; Onyango, P.; Brandenburg, S.; Wu, Y.; Hsieh, C.L.; Feinberg, A.P. Loss of imprinting in colorectal cancer linked to hypomethylation of H19 and IGF2. Cancer Res. 2002, 62, 6442-6446. [PubMed]

131. Ariel, I.; Miao, H.Q.; Ji, X.R.; Schneider, T.; Roll, D.; de Groot, N.; Hochberg, A.; Ayesh, S. Imprinted H19 oncofetal RNA is a candidate tumour marker for hepatocellular carcinoma. Mol. Pathol. 1998, 51, $21-25$. [CrossRef] [PubMed]

132. Byun, H.M.; Wong, H.L.; Birnstein, E.A.; Wolff, E.M.; Liang, G.; Yang, A.S. Examination of IGF2 and H19 loss of imprinting in bladder cancer. Cancer Res. 2007, 67, 10753-10758. [CrossRef] [PubMed]

133. Tanos, V.; Prus, D.; Ayesh, S.; Weinstein, D.; Tykocinski, M.L.; De-Groot, N.; Hochberg, A.; Ariel, I. Expression of the imprinted H19 oncofetal RNA in epithelial ovarian cancer. Eur. J. Obstet. Gynecol. Reprod. Biol. 1999, 85, 7-11. [CrossRef]

134. Fu, X.; Liu, Y.; Zhuang, C.; Liu, L.; Cai, Z.; Huang, W. Synthetic artificial microRNAs targeting UCA1-MALAT1 or c-Myc inhibit malignant phenotypes of bladder cancer cells T24 and 5637. Mol. Biosyst. 2015, 11, 1285-1289. [CrossRef] [PubMed]

135. Barbagallo, D.; Vittone, G.; Romani, M.; Purrello, M. Noncoding RNAs in Health and Disease. Int. J. Genom. 2018, 2018, 9135073. [CrossRef]

136. Tian, Y.; Zhang, X.; Hao, Y.; Fang, Z.; He, Y. Potential roles of abnormally expressed long noncoding RNA UCA1 and Malat-1 in metastasis of melanoma. Melanoma Res. 2014, 24, 335-341. [CrossRef] [PubMed]

137. Liu, Q.; Li, Y.; Lv, W.; Zhang, G.; Tian, X.; Li, X.; Cheng, H.; Zhu, C. UCA1 promotes cell proliferation and invasion and inhibits apoptosis through regulation of the miR129-SOX4 pathway in renal cell carcinoma. Oncol. Targets Ther. 2018, 11, 2475-2487. [CrossRef] [PubMed]

138. Wang, J.; Ye, C.; Liu, J.; Hu, Y. UCA1 confers paclitaxel resistance to ovarian cancer through miR-129/ABCB1 axis. Biochem. Biophys. Res. Commun. 2018, 501, 1034-1040. [CrossRef] [PubMed]

139. Lu, L.; Shen, Y.; Tseng, K.F.; Liu, W.; Duan, H.; Meng, W. Silencing of UCA1, a poor prognostic factor, inhibited the migration of endometrial cancer cell. Cancer Biomark. 2016, 17, 171-177. [CrossRef] [PubMed]

140. Li, Y.; Zheng, Q.; Bao, C.; Li, S.; Guo, W.; Zhao, J.; Chen, D.; Gu, J.; He, X.; Huang, S. Circular RNA is enriched and stable in exosomes: A promising biomarker for cancer diagnosis. Cell Res. 2015, 25, 981-984. [CrossRef] [PubMed]

141. Kulcheski, F.R.; Christoff, A.P.; Margis, R. Circular RNAs are miRNA sponges and can be used as a new class of biomarker. J. Biotechnol. 2016, 238, 42-51. [CrossRef] [PubMed]

142. Xu, H.; Gong, Z.; Shen, Y.; Fang, Y.; Zhong, S. Circular RNA expression in extracellular vesicles isolated from serum of patients with endometrial cancer. Epigenomics 2018, 10, 187-197. [CrossRef] [PubMed]

143. Chen, B.J.; Byrne, F.L.; Takenaka, K.; Modesitt, S.C.; Olzomer, E.M.; Mills, J.D.; Farrell, R.; Hoehn, K.L.; Janitz, M. Analysis of the circular RNA transcriptome in endometrial cancer. Oncotarget 2017, 9, 5786-5796. [CrossRef] [PubMed]

144. Zhai, W.; Li, X.; Wu, S.; Zhang, Y.; Pang, H.; Chen, W. Microarray expression profile of lncRNAs and the upregulated ASLNC04080 lncRNA in human endometrial carcinoma. Int. J. Oncol. 2015, 46, 2125-2137. [CrossRef] [PubMed]

145. Wang, D.; Wang, D.; Wang, N.; Long, Z.; Ren, X. Long Non-Coding RNA BANCR Promotes Endometrial Cancer Cell Proliferation and Invasion by Regulating MMP2 and MMP1 via ERK/MAPK Signaling Pathway. Cell Physiol. Biochem. 2016, 40, 644-656. [CrossRef] [PubMed] 
146. Zhao, X.; Wei, X.; Zhao, L.; Shi, L.; Cheng, J.; Kang, S.; Zhang, H.; Zhang, J.; Li, L.; Zhang, H.; et al. The rs6983267 SNP and long non-coding RNA CARLo-5 are associated with endometrial carcinoma. Environ. Mol. Mutagen. 2016, 57, 508-515. [CrossRef] [PubMed]

147. Xie, P.; Cao, H.; Li, Y.; Wang, J.; Cui, Z. Knockdown of lncRNA CCAT2 inhibits endometrial cancer cells growth and metastasis via sponging miR-216b. Cancer Biomark. 2017, 21, 123-133. [CrossRef] [PubMed]

148. Qiao, Q.; Li, H. LncRNA FER1L4 suppresses cancer cell proliferation and cycle by regulating PTEN expression in endometrial carcinoma. Biochem. Biophys. Res. Commun. 2016, 478, 507-512. [CrossRef] [PubMed]

149. Yang, X.; Wang, C.C.; Lee, W.Y.W.; Trovik, J.; Chung, T.K.H.; Kwong, J. Long non-coding RNA HAND2-AS1 inhibits invasion and metastasis in endometrioid endometrial carcinoma through inactivating neuromedin U. Cancer Lett. 2018, 413, 23-34. [CrossRef] [PubMed]

150. Xin, W.; Liu, X.; Ding, J.; Zhao, J.; Zhou, Y.; Wu, Q.; Hua, K. Long non-coding RNA derived miR-205-5p modulates human endometrial cancer by targeting PTEN. Am. J. Transl. Res. 2015, 7, 2433-2441. [PubMed]

151. Li, W.; Li, H.; Zhang, L.; Hu, M.; Li, F.; Deng, J.; An, M.; Wu, S.; Ma, R.; Lu, J.; et al. Long non-coding RNA LINC00672 contributes to p53 protein-mediated gene suppression and promotes endometrial cancer chemosensitivity. J. Biol. Chem. 2017, 292, 5801-5813. [CrossRef] [PubMed]

152. Pan, X.; Li, D.; Huo, J.; Kong, F.; Yang, H.; Ma, X. LINC01016 promotes the malignant phenotype of endometrial cancer cells by regulating the miR-302a-3p/miR-3130-3p/NFYA/SATB1 axis. Cell Death Dis. 2018, 9, 303. [CrossRef] [PubMed]

153. Guo, Q.; Qian, Z.; Yan, D.; Li, L.; Huang, L. LncRNA-MEG3 inhibits cell proliferation of endometrial carcinoma by repressing Notch signaling. Biomed. Pharmacother. 2016, 82, 589-594. [CrossRef] [PubMed]

154. Li, Z.; Wei, D.; Yang, C.; Sun, H.; Lu, T.; Kuang, D. Overexpression of long noncoding RNA, NEAT1 promotes cell proliferation, invasion and migration in endometrial endometrioid adenocarcinoma. Biomed. Pharmacother. 2016, 84, 244-251. [CrossRef] [PubMed]

155. Yang, C.H.; Zhang, X.Y.; Zhou, L.N.; Wan, Y.; Song, L.L.; Gu, W.L.; Liu, R.; Ma, Y.N.; Meng, H.R.; Tian, Y.L.; et al. LncRNA SNHG8 participates in the development of endometrial carcinoma through regulating c-MET expression by miR-152. Eur. Rev. Med. Pharmacol. Sci. 2018, 22, 1629-1637. [CrossRef] [PubMed]

156. Shang, C.; Lang, B.; Ao, C.N.; Meng, L. Long non-coding RNA tumor suppressor candidate 7 advances chemotherapy sensitivity of endometrial carcinoma through targeted silencing of miR-23b. Tumour Biol. 2017, 39. [CrossRef] [PubMed]

157. Fuldeore, M.J.; Soliman, A.M. Prevalence and Symptomatic Burden of Diagnosed Endometriosis in the United States: National Estimates from a Cross-Sectional Survey of 59,411 Women. Gynecol. Obstet. Investig. 2017, 82, 453-461. [CrossRef] [PubMed]

158. Guo, S.W. Endometriosis and ovarian cancer: Potential benefits and harms of screening and risk-reducing surgery. Fertil. Steril. 2015, 104, 813-830. [CrossRef] [PubMed]

159. Garai, J.; Molnar, V.; Varga, T.; Koppan, M.; Torok, A.; Bodis, J. Endometriosis: Harmful survival of an ectopic tissue. Front. Biosci. 2006, 11, 595-619. [CrossRef] [PubMed]

160. Cho, S.; Mutlu, L.; Grechukhina, O.; Taylor, H.S. Circulating microRNAs as potential biomarkers for endometriosis. Fertil. Steril. 2015, 103, 1252.e1-1260.e1. [CrossRef] [PubMed]

161. Saare, M.; Rekker, K.; Laisk-Podar, T.; Rahmioglu, N.; Zondervan, K.; Salumets, A.; Götte, M.; Peters, M. Challenges in endometriosis miRNA studies-From tissue heterogeneity to disease specific miRNAs. Biochim. Biophys. Acta 2017, 1863, 2282-2292. [CrossRef] [PubMed]

162. Braza-Boils, A.; Marí-Alexandre, J.; Gilabert, J.; Sánchez-Izquierdo, D.; España, F.; Estellés, A.; Gilabert-Estellés, J. MicroRNA expression profile in endometriosis: Its relation to angiogenesis and fibrinolytic factors. Hum. Reprod. 2014, 29, 978-988. [CrossRef] [PubMed]

163. Filigheddu, N.; Gregnanin, I.; Porporato, P.; Surico, D.; Perego, B.; Galli, L.; Patrignani, C.; Graziani, A.; Surico, N. Differential expression of micrornas between eutopic and ectopic endometrium in ovarian endometriosis. J. Biomed. Biotechnol. 2010, 2010, 369549. [CrossRef] [PubMed]

164. Burney, R.O.; Hamilton, A.E.; Aghajanova, L.; Vo, K.C.; Nezhat, C.N.; Lessey, B.A.; Giudice, L.C. MicroRNA expression profiling of eutopic secretory endometrium in women with versus without endometriosis. Mol. Hum. Reprod. 2009, 15, 625-631. [CrossRef] [PubMed] 
165. Laudanski, P.; Charkiewicz, R.; Kuzmicki, M.; Szamatowicz, J.; Charkiewicz, A.; Niklinski, J. MicroRNAs expression profiling of eutopic proliferative endometrium in women with ovarian endometriosis. Reprod. Biol. Endocrinol. 2013, 11, 78. [CrossRef] [PubMed]

166. Kim, M.K.; Lee, S.K.; Park, J.H.; Lee, J.H.; Yun, B.H.; Park, J.H.; Seo, S.K.; Cho, S.; Choi, Y.S. Ginsenoside Rg3 Decreases Fibrotic and Invasive Nature of Endometriosis by Modulating miRNA-27b: In Vitro and In Vivo Studies. Sci. Rep. 2017, 7, 17670. [CrossRef] [PubMed]

167. Zhao, L.; Gu, C.; Ye, M.; Zhang, Z.; Li, L.; Fan, W.; Meng, Y. Integration analysis of microRNA and mRNA paired expression profiling identifies deregulated microRNA-transcription factor-gene regulatory networks in ovarian endometriosis. Reprod. Biol. Endocrinol. 2018, 16, 4. [CrossRef] [PubMed]

168. Laschke, M.W.; Menger, M.D. In vitro and in vivo approaches to study angiogenesis in the pathophysiology and therapy of endometriosis. Hum. Reprod. Update 2007, 13, 331-342. [CrossRef] [PubMed]

169. Ohlsson-Teague, E.M.; Print, C.G.; Hull, M.L. The role of microRNAs in endometriosis and associatedreproductive conditions. Hum. Reprod. Update 2010, 16, 142-165. [CrossRef] [PubMed]

170. Braza-Boïls, A.; Gilabert-Estellés, J.; Ramón, L.A.; Gilabert, J.; Marí-Alexandre, J.; Chirivella, M.; España, F.; Estellés, A. Peritoneal fluid reduces angiogenesis-related microRNA expression in cell cultures of endometrial and endometriotic tissues from women with endometriosis. PLoS ONE 2013, 8, e62370. [CrossRef] [PubMed]

171. Liu, X.J.; Bai, X.G.; Teng, Y.L.; Song, L.; Lu, N.; Yang, R.Q. miRNA-15a-5p regulates VEGFA in endometrial mesenchymal stem cells and contributes to the pathogenesis of endometriosis. Eur. Rev. Med. Pharmacol. Sci. 2016, 20, 3319-3326. [PubMed]

172. Harp, D.; Driss, A.; Mehrabi, S.; Chowdhury, I.; Xu, W.; Liu, D.; Garcia-Barrio, M.; Taylor, R.N.; Gold, B.; Jefferson, S.; et al. Exosomes derived from endometriotic stromal cells have enhanced angiogenic effects in vitro. Cell Tissue Res. 2016, 365, 187-196. [CrossRef] [PubMed]

173. Hull, M.L.; Nisenblat, V. Tissue and circulating microRNA influence reproductive function in endometrial disease. Reprod. Biomed. Online 2013, 27, 515-529. [CrossRef] [PubMed]

174. Yang, L.; Liu, H.Y. Small RNA molecules in endometriosis: Pathogenesis and therapeutic aspects. Eur. J. Obstet. Gynecol. Reprod. Biol. 2014, 183, 83-88. [CrossRef] [PubMed]

175. Nothnick, W.B.; Al-Hendy, A.; Lue, J.R. Circulating Micro-RNAs as Diagnostic Biomarkers for Endometriosis: Privation and Promise. J. Minim. Invasive Gynecol. 2015, 22, 719-726. [CrossRef] [PubMed]

176. Wang, W.T.; Zhao, Y.N.; Han, B.W.; Hong, S.J.; Chen, Y.Q. Circulating microRNAs identified in a genome-wide serum microRNA expression analysis as noninvasive biomarkers for endometriosis. J. Clin. Endocrinol. Metab. 2013, 98, 281-289. [CrossRef] [PubMed]

177. Jia, S.Z.; Yang, Y.; Lang, J.; Sun, P.; Leng, J. Plasma miR-17-5p, miR-20a and miR-22 are down-regulated in women with endometriosis. Hum. Reprod. 2013, 28, 322-330. [CrossRef] [PubMed]

178. Rekker, K.; Saare, M.; Roost, A.M.; Kaart, T.; Sõritsa, D.; Karro, H.; Sõritsa, A.; Simón, C.; Salumets, A.; Peters, M. Circulating miR-200-family micro-RNAs have altered plasma levels in patients with endometriosis and vary with blood collection time. Fertil. Steril. 2015, 104, 938-946. [CrossRef] [PubMed]

179. Ghazal, S.; McKinnon, B.; Zhou, J.; Mueller, M.; Men, Y.; Yang, L.; Mueller, M.; Flannery, C.; Huang, Y.; Taylor, H.S. H19 lncRNA alters stromal cell growth via IGF signaling in the endometrium of women with endometriosis. EMBO Mol. Med. 2015, 7, 996-1003. [CrossRef] [PubMed]

180. Ren, S.; Liu, Y.; Xu, W.; Sun, Y.; Lu, J.; Wang, F.; Wei, M.; Shen, J.; Hou, J.; Gao, X.; et al. Long noncoding RNA MALAT-1 is a new potential therapeutic target for castration resistant prostate cancer. J. Urol. 2013, 190, 2278-2287. [CrossRef] [PubMed]

181. Fan, Y.; Shen, B.; Tan, M.; Mu, X.; Qin, Y.; Zhang, F.; Liu, Y. TGF-beta-induced upregulation of malat1 promotes bladder cancer metastasis by associating with suz12. Clin. Cancer Res. 2014, 20, 1531-1541. [CrossRef] [PubMed]

182. Zhao, Z.; Chen, C.; Liu, Y.; Wu, C. 17 beta-Estradiol treatment inhibits breast cell proliferation, migration and invasion by decreasing MALAT-1 RNA level. Biochem. Biophys. Res. Commun. 2014, 445, 388-393. [CrossRef] [PubMed]

183. Li, Q.; Zhang, C.; Chen, R.; Xiong, H.; Qiu, F.; Liu, S.; Zhang, M.; Wang, F.; Wang, Y.; Zhou, X.; et al. Disrupting MALAT1/miR-200c sponge decreases invasion and migration in endometrioid endometrial carcinoma. Cancer Lett. 2016, 383, 28-40. [CrossRef] [PubMed] 
184. Liang, Z.; Chen, Y.; Zhao, Y.; Xu, C.; Zhang, A.; Zhang, Q.; Wang, D.; He, J.; Hua, W.; Duan, P. miR-200c suppresses endometriosis by targeting MALAT1 in vitro and in vivo. Stem Cell Res. Ther. 2017, 8, 251. [CrossRef] [PubMed]

185. Cravello, L.; Porcu, G.; D’Ercole, C.; Roger, V.; Blanc, B. Identification and treatment of endometritis. Contracept. Fertil. Sex. 1997, 25, 585-586. [PubMed]

186. Gilmore, H.; Fleischhacker, D.; Hecht, J.L. Diagnosis of chronic endometritis in biopsies with stromal breakdown. Hum. Pathol. 2007, 38, 581-584. [CrossRef] [PubMed]

187. Johnston-MacAnanny, E.B.; Hartnett, J.; Engmann, L.L.; Nulsen, J.C.; Sanders, M.M.; Benadiva, C.A. Chronic endometritis is a frequent finding in women with recurrent implantation failure after in vitro fertilization. Fertil. Steril. 2010, 93, 437-441. [CrossRef] [PubMed]

188. Cicinelli, E.; Matteo, M.; Tinelli, R.; Pinto, V.; Marinaccio, M.; Indraccolo, U.; De Ziegler, D.; Resta, L. Chronic endometritis due to common bacteria is prevalent in women with recurrent miscarriage as confirmed by improved pregnancy outcome after antibiotic treatment. Reprod. Sci. 2014, 21, 640-647. [CrossRef] [PubMed]

189. Taylor, S.; Frydman, R. Hysteroscopy and sperm infection. Contracept. Fertil. Sex. 1996, 24, 549-551. [PubMed]

190. Féghali, J.; Bakar, J.; Mayenga, J.M.; Ségard, L.; Hamou, J.; Driguez, P.; Belaisch-Allart, J. Systematic hysteroscopy prior to in vitro fertilization. Gynecol. Obstet. Fertil. 2003, 31, 127-131. [CrossRef]

191. Espinoza, J.; Erez, O.; Romero, R. Preconceptional antibiotic treatment to prevent preterm birth in women with a previous preterm delivery. Am. J. Obstet. Gynecol. 2006, 194, 630-637. [CrossRef] [PubMed]

192. Di Pietro, C.; Cicinelli, E.; Guglielmino, M.R.; Ragusa, M.; Farina, M.; Palumbo, M.A.; Cianci, A. Altered transcriptional regulation of cytokines, growth factors and apoptotic proteins in the endometrium of infertile women with chronic endometritis. Am. J. Reprod. Immunol. 2013, 69, 509-517. [CrossRef] [PubMed]

193. Matteo, M.; Cicinelli, E.; Greco, P.; Massenzio, F.; Baldini, D.; Falagario, T.; Rosenberg, P.; Castellana, L.; Specchia, G.; Liso, A. Abnormal pattern of lymphocyte subpopulations in the endometrium of infertile women with chronic endometritis. Am. J. Reprod. Immunol. 2009, 61, 322-329. [CrossRef] [PubMed]

194. Kitaya, K.; Yasuo, T. Immunohistochemistrical and clinicopathological characterization of chronic endometritis. Am. J. Reprod. Immunol. 2011, 66, 410-415. [CrossRef] [PubMed]

195. Park, H.J.; Kim, Y.S.; Yoon, T.K.; Lee, W.S. Chronic endometritis and infertility. Clin. Exp. Reprod. Med. 2016, 43, 185-192. [CrossRef] [PubMed]

196. Guzeloglu-Kayisli, O.; Kayisli, U.A.; Taylor, H.S. The role of growth factors and cytokines during implantation: Endocrine and paracrine interactions. Semin. Reprod. Med. 2009, 27, 62-79. [CrossRef] [PubMed]

197. Di Pietro, C.; Caruso, S.; Battaglia, R.; Iraci Sareri, M.; La Ferlita, A.; Strino, F.; Bonaventura, G.; Di Mauro, M.; Barcellona, M.L.; Perciavalle, V.; et al. MiR-27a-3p and miR-124-3p, upregulated in endometrium and serum from women affected by Chronic Endometritis, are new potential molecular markers of endometrial receptivity. Am. J. Reprod. Immunol. 2018, 16, e12858. [CrossRef] [PubMed]

198. Hailemariam, D.; Ibrahim, S.; Hoelker, M.; Drillich, M.; Heuwieser, W.; Looft, C.; Cinar, M.U.; Tholen, E.; Schellander, K.; Tesfaye, D. MicroRNA-regulated molecular mechanism underlying bovine subclinical endometritis. Reprod. Fertil. Dev. 2014, 26, 898-913. [CrossRef] [PubMed]

199. Dimitriadis, E.; White, C.A.; Jones, R.L.; Salamonsen, L.A. Cytokines, chemokines and growth factors in endometrium related to implantation. Hum. Reprod. Update 2005, 11, 613-630. [CrossRef] [PubMed]

(C) 2018 by the authors. Licensee MDPI, Basel, Switzerland. This article is an open access article distributed under the terms and conditions of the Creative Commons Attribution (CC BY) license (http://creativecommons.org/licenses/by/4.0/). 